Scottish Journal of Geology, Volume 50, 97-123, 2014: doi.org/10.1144/sjg2014-001

Note that this version of the text does not include all of the final amendments added in proof by the $S J G$ editor.

\title{
The Southern Uplands Terrane in Scotland - a notional controversy revisited
}

\author{
Philip Stone \\ British Geological Survey, Murchison House, West Mains Rd, Edinburgh EH9 3LA \\ (e-mail: psto@bgs.ac.uk)
}

\section{Synopsis}

Development of a regional geological interpretation for the Southern Uplands Terrane has been driven historically by advances in graptolite biostratigraphy, sandstone petrography and turbidite sedimentology (particularly the recognition of reliable wayup criteria), then, more recently, by a growing appreciation of the nature of accretionary processes at active plate margins. The latter has led to the widely held view of the terrane as an archetypal fossil accretionary prism, built up by the accretion at the margin of Laurentia of the sedimentary cover of Iapetus oceanic crust, the cover being stripped from the oceanic crust during its subduction beneath Laurentia. The achievement of this broad consensus has not been without controversy, which still persists in respect of some aspects of the overall model. Suggestions that the northernmost (Ordovician) part of the terrane might have originated in a back-arc basin have been disproved by a combination of mineral dating and basin thermal history analysis utilising clay mineralogy. Nevertheless, it remains possible for that part of the terrane to have a continental margin, fore-arc depositional history. The southernmost (mid-Silurian) part of the terrane most probably developed in a foreland basin setting, as a fold and thrust belt over-riding Avalonia, following the closure of the Iapetus Ocean. Progress in understanding the origins of the Southern Uplands Terrane has only been achieved by the collaborative application of multidisciplinary techniques - biostratigraphic, sedimentary, structural, geochemical and geophysical. This review is a tribute to all those who have contributed.

\section{Introduction}


The Southern Uplands Terrane is arguably the World's best-preserved ancient accretionary complex. It occupies about $10000 \mathrm{~km}^{2}$ of southern Scotland and about 6 $000 \mathrm{~km}^{2}$ in the Down-Longford region of Ireland and is the southernmost of the exposed Laurentian terranes of the British Isles. The Terrane is characterised by Ordovician and Silurian turbidite successions of sandstone, siltstone and mudstone that have been deformed such that bedding dip commonly approaches the vertical or is overturned. A superficial uniformity of lithology and structure camouflages the terrane's complexity, and its understanding has only been achieved by the integration of a range of geological techniques. Although widely advertised as a controversy, following McKerrow (1987), the cooperative and amicable teasing-out of the region's geological problems should rather be seen as an exemplary illustration of collaborative scientific methodology. This review will attempt to explore the ways in which the particular issues raised by Southern Uplands geology have been addressed, drawing principally on research in the terrane's Scottish sector. There is no pretence that it is a comprehensive review of all aspects of the regional geology. A different reviewer may well have selected a radically different path through the Southern Uplands geological historiography.

The geological framework, essential background for what follows hereinafter, is summarised in Figures $1 \&$ 2. Figure 1a shows the outline geology which is dominated by a series of large-scale, strike-parallel faults, extending NE-SW, that separate successions of Ordovician and Silurian, mainly turbidite strata. The currently defined arrangement of these fault-bounded units, described in the Southern Uplands literature as structural tracts and commonly assigned lithostratigraphical status as formations, is summarised in Figure 1b. Coloured versions of both Figure 1 maps, showing details of the regional lithostratigraphy, are available as supplementary material to the on-line version of this paper. Throughout the terrane, bedding dip is generally steep and the succession seen in each tract usually youngs towards the NW. At the base of the succession in each tract an assemblage of chert and graptolitic mudstone (very rarely, and only in the Ordovician tracts, with subjacent basaltic lavas) lies immediately to the NW of a major strike-parallel fault; the mudstone is conformably overlain by a very much thicker sequence of turbidite siltstone and sandstone. The top of the siltstone-sandstone unit is then cut out by a strike-parallel 
fault that reintroduces the mudstone-chert assemblage at the stratigraphical base of the next tract north-westward. At the NW margin of the terrane the biostratigraphic range of the mudstone is restricted to one or two mid-Ordovician graptolite biozones (representing only 2 or 3 million years), but progressively towards the SE the range increases until the mudstone unit spans the Late Ordovician and Early Silurian (up to 25 million years). As a result, the age of the turbidite siltstone-sandstone unit in each tract (which only rarely spans more than a single graptolite biozone) decreases southeastward, from Early Caradoc (Sandbian) to Early Wenlock; this is the arrangement shown graphically in Figure 2. Within each tract the strata young towards the NW but over the entire terrane the strata in the SE are younger than those in the NW. This is the Southern Uplands paradox, summed up by Anderson \& Cameron (1979, p. 263) from the Ards Peninsula, Northern Ireland, as follows: "Folding and stratigraphy combine in the classic Southern Uplands paradox: although north-younging limbs are predominant, graptolites invariable indicate the presence of younger sediments to the south."

\section{The major historical contributions}

Graptolite biostratigraphy provided the key to an understanding of Southern Uplands geology. Lapworth $(1872,1878)$ first recognised the tripartite internal stratigraphy of the 'Moffat Shale' and then established a regionally applicable succession of biozones based on meticulous fieldwork at Dob's Linn, $15 \mathrm{~km}$ NE of Moffat. He recognised and named, in upward succession, the Glenkiln, Hartfell and Birkhill shales. Lapworth was not the only palaeontologist researching Southern uplands graptolites (Rushton 2001), but it was undoubtedly his biostratigraphical insight that formed the basis for a regional understanding. To capitalise on the opportunity, the Geological Survey dispatched the authoritative figures of Peach and Horne to mastermind the remapping of the Southern Uplands, ably supported by the fossil collector Macconochie. The ensuing Peach \& Horne (1899) Memoir - The Silurian Rocks of Britain. Volume 1, Scotland - stands as a classic of Victorian science and remains a valuable data source.

Peach \& Horne (1899) is a necessary starting point in any consideration of Southern Uplands geology but, as a precursor, a cameo of Dob's Linn is appropriate since the 
succession there is representative of the broader Southern Uplands pattern. Lapworth's (1878) original map of the area remains a valid representation of the geology. It has a large format, shows a plethora of detail and has been reproduced in more recent publications (e.g. Figure 11.2 of Clarkson \& Upton 2010). At Dob's Linn the Moffat Shale Group mudstones strike broadly NE-SW and form one of the most continuous basal successions seen in any of the Southern Upland tracts. The SE limit of the mudstones is marked by a major strike-parallel fault, whilst at their NW limit the mudstones are abruptly and conformably succeeded by Gala Group sandstone beds. The Moffat Shale Group mudstones span about 15 graptolite biozones from the Early Caradoc (Ordovician) to the mid-Llandovery (Silurian) in about $80 \mathrm{~m}$ of strata (Figure 3). Interbedded within the mudstones are numerous thin layers of volcanic ash (metabentonites); from the Upper Hartfell and Birkhill Shales Merriman \& Roberts (1990) described 138 metabentonite layers, comprising up to $20 \%$ of the total (compacted) succession in some graptolite biozones (Figure 3). The fine biostratigraphical control available at Dob's Linn, coupled with radiometric dates from zircon in the metabentonites (Tucker et al. 1990) has enabled the section to be established as the international stratotype for the base of the Silurian System (e.g. Williams 1988).

Peach \& Horne's (1899) reappraisal of Southern Uplands geology utilised and extended Lapworth's biostratigraphy but they lacked the sedimentological and structural keys that were to prove crucial. The significance of neither the sedimentological features allowing the 'way-up' of steeply inclined strata to be established (graded bedding, cross-lamination, sole structures etc.), nor the structural importance of fold vergence were appreciated, and so the Southern Uplands' paradoxical arrangement of stratigraphy was not recognised. Instead, Peach and Horne developed a structural model of the Southern Uplands in which tight folding dominated (Figure 4a). The folding is locally real enough but is fundamentally asymmetric with predominantly southwards vergence. Without this constraint on their regional model (but note the reverse fault at F in Figure 4) they explained the progressively southward younging biostratigraphy as arising from an intensely folded stratigraphy accommodated within a large-scale 'anticlinorium-synclinorium' system and defined the region in terms of a Northern Belt of Ordovician (Caradoc and Ashgill) age, a Central Belt of Silurian (Llandovery) age and a Southern Belt of 
Silurian (Wenlock) age. These broad regional terms are still widely used, although their chronostratigraphical exclusivities have faltered.

It was not until the early 1950s that the application of advances in sedimentology began to unpick Peach and Horne's geological model. Kuenen (1953, pp 44-45) recognised the upright strata exposed on the south-west coast of the Southern Uplands (the Rhins of Galloway peninsula) as having been deposited by turbidity currents and, using graded bedding as his main guide, noted with evident surprise that "all along this coastal section the bottom of the graded beds ... lies on their southern side. The northern [sic] limbs of the isoclinal structures appear to be entirely suppressed". His surprise would have arisen from the expectation that, if Peach and Horne's model was correct, there would be about as much south-younging as north-younging strata. Building on Keunen's reconnaissance, the Rhins of Galloway 'type area' was soon described in detail by Kelling (1961). The new insight also forced a reconsideration of the regional structure and in a radical reinterpretation Craig \& Walton (1959) proposed a series of large monoclines, each with steep limbs to the north and flat limbs cut on their south side by major strike-parallel reverse faults with substantial downthrow to the south. The steeply dipping, northern limbs contained uniformly north-younging strata; the flat limbs were corrugated by minor folds within a horizontal fold envelope that was faulted against the next steep limb southward. This model provided the starting-point for the accretionary thrust interpretations that were to follow as plate tectonics came to the fore.

\section{Subduction, accretion and the Iapetus Ocean}

The advent of plate tectonic theory revolutionised many geological interpretations, and that of the Southern Uplands Terrane was no exception. It led to the Southern Uplands being modelled as an accretionary thrust complex formed above a northdipping subduction zone at the Laurentian (northern) continental margin of the Early Palaeozoic Iapetus Ocean (McKerrow et al. 1977; Leggett et al 1979). This subduction zone eventually became the plane of collision - the Iapetus Suture between Laurentia and the southern continent of Avalonia when the Iapetus Ocean closed. The suture appears as a prominent NW-dipping reflector on several deep seismic profiles across the Southern Uplands, and projects to the surface to the north 
of the English Lake District and the Isle of Man; the evidence has been reviewed by Soper et al. (1992a).

The existence of the Iapetus Ocean had long been presaged by the recognition of counter-intuitive similarities and contrasts of Early Palaeozoic faunal assemblages along and across the Caledonian Orogen. For example, in southern Scotland, Williams (1962) showed that the Ordovician brachiopod faunas from the Girvan succession bore a striking resemblance to those of the Appalachian region of North America, but showed little similarity to those of Wales. The palaeontological contrast - faunal provinciality - diminished with time until, by the Late Silurian and as a result of a decreasing oceanic separation, the fossil faunas became relatively cosmopolitan. The evidence of faunal provinciality and the history of its establishment has been reviewed and assessed by Cocks \& Fortey (1982 and references therein) and pointed to a wide, Early Palaeozoic ocean separating equatorial Laurentia, to the north, from temperate Avalonia and other peri-Gondwanan continental fragments to the south.

As the Iapetus Ocean began to close, subduction beneath the margin of Laurentia initiated the formation of an accretionary thrust complex - the accretionary prism model. There are modern analogues for this process at several actively convergent plate margins, and these examples have been used to inform the Southern Uplands debate, although none provide a comprehensive comparison. Leggett et al. (1983) and Leggett (1987) discussed the attributes of several modern examples, including the SW Japan and Sumatra fore-arcs, and emphasised broad similarities with the Southern Uplands whilst admitting much detailed variation. Another useful analogue is provided by the Late Cretaceous to Cenozoic, Kodiak accretionary complex in Alaska (Sample \& Moore 1987) which was used by Merriman \& Roberts (2001) as an aid to the interpretation of structural and metamorphic patterns in the Southern Uplands.

The strata incorporated into the Southern Uplands accretionary complex originated as sand and mud carried by turbidity currents from the continental shelf, via submarine canyons, and built up into huge depositional fans. The turbidite deposits filled the supra-subduction-zone trench and encroached onto the oceanic plate, where they covered the sequence of hemipelagic mud (Moffat Shale Group), radiolarian chert and pillow lava (Crawford Group). As the submarine fans built out they overstepped 
progressively younger oceanic sequences that were continually approaching the continental margin as the oceanic plate was subducted. Then, during the subduction process, discrete sections of the oceanic sequence and its cover of turbidite sandstone were sequentially stripped from the subducting oceanic plate and thrust beneath the stack of similarly stripped-off slices that made up the growing accretionary complex. These slices, structurally rotated towards the vertical (and in places even beyond it so that the component beds are inverted), now give rise to the characteristic Southern Uplands lithostratigraphic outcrop pattern of upright beds contained in elongated and NE-SW-trending, fault-bounded tracts which are defined stratigraphically in terms of groups and formations (Figures $1 \& 2$ and the supplementary material).

The origins of the accretionary prism model can be traced back to such landmark papers as Wilson (1966) and Dewey (1969) which developed the theme of an opening and closing Iapetus Ocean within the Caledonian Orogen. Dewey (1971) then focused on the Early Palaeozoic evolution of the Scotland-Ireland sector of the Laurentian margin as the Iapetus Ocean closed. Tellingly, Dewey identified the Southern Upland succession as a wedge of clastic sediment that initially built up in a continental margin trench, but then extended out across the subducting oceanic plate. Deformation was caused by shortening of the sedimentary succession accompanied by segmentation of the oceanic crust (Dewey 1971, see his figure 5), processes giving rise to a structural geometry similar to that proposed by Craig \& Walton (1959). Figure 3 of Dewey's 1971 paper is a stratigraphical correlation chart within which the eight Southern Uplands columns form a time-stratigraphical series of the type that was to become familiar: each column showed the onset of turbidite sedimentation, conformably succeeding graptolitic mudstone, becoming progressively younger southward. A modern successor is shown in Figure 2 of this paper.

Dewey's interpretation foreshadowed the development of the full-blown accretionary prism model (Figure 5) through a series of papers by McKerrow, Leggett and coworkers (Mitchell \& McKerrow 1975; McKerrow et al. 1977; Leggett et al. 1979, 1982, 1983). Another likely influence was the illustration of an essentially thrust geometry for at least part of the Southern Uplands by Fyfe \& Weir (1976), although the significance of this paper, and a precursor interpretation by Toghill (1970), has not generally received the acknowledgement that it deserves. Fyfe \& Weir's structural 
cross sections across the Ettrick Valley are reproduced as Figure $4 \mathrm{~b}$ as a comparison to Peach \& Horne's (1899) cross-section of the same general area to the NE of Moffat, at the head of the Ettrick Water valley. In his referee's report on this paper, Dr T. Needham made the pertinent observation that Fyfe \& Weir's cross-sections do not show a regular sequence of imbrication, instead hinting at extensional or strikeslip reactivation.

The idealised accretionary prism as envisaged by McKerrow et al. (1977) is shown in Figure 5a, with a more recent representation by Stone (1995) following as Figure 5b. McKerrow et al. show the prism developing in size with, by the Early to Middle Silurian, the emergence of a trench-slope break, labelled "Cockburnland". The name had originally been coined (in memory of a deceased colleague) by Walton (1963) to describe a dominantly igneous landmass further north, which was thought to be the provenance of the Late Ordovician conglomerates found in the Northern Belt of the Southern Uplands. As applied by McKerrow et al., Cockburnland mostly comprised turbidite sandstone and was thought to be the provenance for Silurian conglomerates and sandstones deposited along the southern margin of the Midland Valley Terrane. This link was undermined by subsequent work (to be discussed later in this account) that demonstrated significant compositional differences between the Midland Valley rocks and their putative Southern Uplands source. Accordingly, the status of Cockburnland as an emergent landmass is now uncertain, but the growing accretionary prism is highly likely to have provided recycled sediment into the younger deposits of the Southern Uplands. At the largest scale, this involved the slumped sedimentary fill of trench slope basins as identified, for example, in the Coldingham area (Figure 1) by Leggett et al. (1982, p. 511). Cockburnland, as an emergent trench-slope break, was identified by Leggett et al. $(1982,1983)$ as a feature that could be broadly correlated with the modern analogue of the Mentawai Islands in the Sumatran fore-arc.

Perhaps the most curious feature of the Southern Uplands accretionary prism stressed by Leggett et al. (1982) was that, from the geophysical evidence, it appeared to lie as an allochthonous unit above continental crust. Nevertheless, the basaltic substrate to the turbidite successions (which now forms part of the Crawford Group) would, in the context of the accretionary prism model, be regarded as vestiges of oceanic crust and 
so its composition and geochemical characteristics should be compatible with such an origin. A number of studies have attempted to confirm the association. The results (summarised by Smith et al. 2001) have proved ambiguous, with conflicting reports of the basaltic rocks having ocean ridge (MORB), island arc or within-plate geochemistry. More definitively, the volcanic rocks forming the substantial Bail Hill Volcanic Group (Phillips et al. 1999) have been shown to be alkaline in character, ranging from alkali basalt to trachyandesite, with the whole-rock geochemical characteristics and enrichment patterns of oceanic, within-plate basalt. The Bail Hill Volcanic Group is the largest component of a mixed assemblage of tholeiitic and alkaline, oceanic within-plate lavas that are distributed through the Northern Belt of the Southern Uplands, in places intercalated with the turbidite sequences rather than underlying it. Oceanic within-plate volcanism was thus contemporaneous with the early development of the Southern Uplands accretionary complex, producing ocean island successions that were subsequently subducted and incorporated into the growing prism.

The accretionary prism model is an elegant solution to the principal geological problems posed by the Southern Uplands Terrane, but when first proposed enough issues appeared unresolved to prevent its immediate and universal acceptance. A particular conundrum arose from different Southern Uplands tracts having different detrital grain assemblages accompanied by different palaeocurrent regimes, a phenomenon that had been known for some time (e.g Walton 1955), but which now seemed to have a particular bearing on the accretionary prism interpretation. Murphy $\&$ Hutton (1986) described microconglomerates from the Irish Silurian sector of the terrane, some apparently derived from the north and others from the south side of the depositional basin, yet all showing a similar, magmatic arc provenance. The proposed explanation envisaged closure of the Iapetus Ocean at the end of the Ordovician, with supra-subduction, Ordovician volcanism synchronously ceasing at both its northern and southern margins. Erosion of the arc complexes then fed similar sediment, from both the north and the south, into a Silurian successor basin lying above the line of ocean closure. Morris (1987) and Stone et al. (1987) noted, from Ireland and Scotland respectively, that within the Ordovician tracts abundant and fresh-looking andesitic grains characterised sandstones that appeared to have been derived from the south, i.e. from an oceanward direction. From that perspective the northern part of the Southern 
Uplands, largely comprising the Ordovician succession, seemed to have been deposited in a back-arc environment rather than at an accretionary fore-arc.

These challenges to the accretionary prism model, and the responses of its proponents, were dubbed "The Southern Uplands Controversy" by McKerrow (1987) who, in February 1986, had convened a Geological Society of London symposium to discuss the issues. Contributions to the symposium that were to become fundamental to the regional debate were provided by Leggett (1987) who championed the fore-arc accretionary prism model placing much weight on modern analogues, Morris (1987) who developed the back-arc interpretation for the Ordovician Northern Belt based on data from Ireland, and Stone et al (1987) who put forward an interpretation involving development of a back-arc to foreland basin thrust duplex. Although these different approaches were underpinned by a common theme - the assembly of the Southern Uplands Terrane, by whatever means, occurred at the northern, active margin of the Iapetus Ocean, where oceanic crust was lost by subduction - McKerrow (1987, p. 735) acknowledged that "before any general consensus can be reached more field evidence is needed."

Initially, the next phase of field investigations moved further from a consensus rather than towards it. An alternative proposal by Armstrong et al. (1996) for the origin of the Ordovician Northern Belt was based on detailed biostratigraphy and correlation with the coeval Girvan succession of the Midland Valley Terrane. Armstrong et al. (1996) regarded the Northern Belt strata as having been deposited as prograding submarine fans at a subsiding and extending continental margin, effectively as the more distal equivalent of the Girvan succession although requiring a more varied provenance. Basic lava and chert intimately associated with the some of the Northern Belt sedimentary units were thought to be indicative of an attenuated rift environment. This interpretation placed Northern Belt sedimentation in an extensional fore-arc setting (relative to the established Midland Valley arc magmatism) and, the authors felt (Armstrong et al. 1996, Abstract), "confounds the accretionary prism model” for the Southern Uplands which would require a compressional regime. This may well have been a deliberately provocative overstatement, but further evidence for a continental margin (as opposed to oceanic) setting for Northern Belt sedimentation was provided by Owen et al. (1999) derived from the rare-earth geochemistry of the 
basal cherts, which established that they were not wholly oceanic but had received a terrigenous input.

The sequence of proposals and counter-proposas described above, and the increasing tempo of work in their aftermath, were discussed in authoritative detail by Kelling (2001) at a 1999 symposium celebrating the publication centenary of the seminal Peach \& Horne, Geological Survey memoir. The other papers that were presented ranged across the geological spectrum of the Southern Uplands and illustrated the diverse ways in which McKerrow's appeal for more data had been met. There was still no unequivocal approval for the accretionary prism model, but it had clearly gained ground on the alternatives that involved Ordovician sedimentation and deformation in a back-arc basin environment. The general feeling was typified by Anderson (2001, p. 371) who concluded after a detailed review of structural interpretations:

"While the two currently competing models, fore-arc accretionary prism and back-arc to foreland basin thrust duplex, both offer viable interpretations of current structural cross-sections, the essentially thin-skinned nature of the latter model demands assumptions which make it a less attractive explanation."

Anderson might well have added the third possibility for the origin of the Northern Belt that had been raised by Armstrong et al. (1996). This extensional fore-arc interpretation was then developed further by Armstrong \& Owen (2001) as part of a comprehensive remodelling of terrane amalgamation across the paratectonic Caledonides of northern Britain, drawing support from correlations with Newfoundland. For the Southern Uplands, this remodelling involved the southdirected thrust imbrication of the Northern Belt's continental margin succession to override a continental block, named "Novantia" by Armstrong \& Owen, which was thought by Kimbell \& Stone (1995) to have peri-Gondwanan rather than Laurentian geophysical characteristics. In the Armstrong \& Owen model, thrust imbrication was initiated by collision of an outboard arc terrane with the ocean-facing, southern margin of Novantia. The earlier collision of Novantia with the Midland Valley Terrane was thought to have driven obduction of the Ballantrae Complex before relaxation and subsidence allowed the spread of the Northern Belt submarine fans. Thereafter, following collision of the outboard arc and the southward thrusting of the 
Ordovician tracts, the Silurian successions of the Southern Uplands built up as in a foreland basin thrust belt; there are similarities at this stage with the earlier, back-arc to foreland basin model of Stone et al. (1987). The Newfoundland correlations owed much to van Staal et al. (1998).

So, at the end of the $20^{\text {th }}$ century, a range of explanations were available for the origins of the Southern Uplands Terrane. The entire terrane had been proposed as an accretionary prism formed from the sedimentary cover of Iapetus oceanic crust as it was subducted beneath the margin of Laurentia (McKerrow et al. 1977, Leggett et al. 1979); subduction operated continuously from the mid-Ordovician until the late Silurian, when the Iapetus Ocean closed. Alternatively, the northern (Ordovician and perhaps oldest Silurian) strata had been interpreted as the deposits of either a back arc basin (Morris 1987; Stone et al. 1987) or an extending and subsiding fore-arc (Armstrong et al. 1996). The southern (Silurian) strata had been interpreted as originating either in a foreland basin that migrated onto the Avalonian continental margin following mid-Silurian closure of the Iapetus Ocean (Stone et al., or in a successor basin lying above the Laurentia-Avalonia continental suture following endOrdovician closure of the Iapetus Ocean (Murphy \& Hutton 1986). All of these interpretations then invoked various combinations of thrust and strike-slip tectonics to produce the terrane's characteristic regional structure. Of the alternatives, the comprehensive accretionary prism model was undoubtedly the clear favourite but its definitive proof remained elusive.

As the new millennium began, McKerrow's (1987) request for more field data had certainly been answered, but in terms of the main issue - the proof or otherwise of the accretionary prism model - there was still no clear resolution. Instead, the range of alternatives on offer had increased. The following sections of this review will explore the multidisciplinary ways in which that 'main issue' has been more recently addressed.

\section{Biostratigraphy}

Rushton (2001) reviewed progress in graptolite biostratigraphy since the days of Lapworth, Peach and Horne. Notable was the increasing refinement of biozonation, 
which had resulted in a doubling of the recognised divisions relative to the twelve in Lapworth's original (1878) scheme. The currently applied series of zones and subzones has been established in a comprehensive review of the evidence by Zalasiewicz et al. (2009). In the Southern Uplands, the principal effect of the biostratigraphical refinement has been to allow the recognition of a more detailed arrangement of structural tracts, a process complemented by new fossil discoveries. For example, the Ashgill faunas of the Glenlee Formation, the southernmost of the Ordovician tracts (Figure 2), were only identified relatively recently (Floyd \& Rushton 1993).

The cross-strike, time-stratigraphic profiles now used to illustrate the Southern Uplands tract assemblage (Figure 2) show a much greater level of detail than was possible in the early expositions of the accretionary prism model by Leggett et al. (1979, 1982). Nevertheless, the same limitations are still imposed by the restricted nature of the faunas at any one locality. The cross-strike profile is determined by the youngest graptolite fauna obtained from the Moffat Shale Group, from beds immediately beneath the overlying turbidite sandstone, in each structural tract. It is always possible that the truly youngest fauna has been missed during collecting, or that the strata containing it have been tectonically excised; most Moffat Shale outcrops are indeed sheared and disrupted. However, the rare discoveries of graptolitic interbeds within the overlying turbidite successions have always proved to be indicative of either the same graptolite biozone as proved from the youngest part of the underlying Moffat Shale Group, or of the next youngest biozone. In the southern part of the terrane, Moffat Shale is not seen to underlie much of the Hawick Group or the Riccarton Group, and for these divisions the biostratigraphical control is limited to fossiliferous interbeds. These are rare and so provide only sparse biostratigraphical control in the Hawick Group, but are relatively abundant in the Riccarton Group for which the control is, accordingly, very good.

From the improved biostratigraphical resolution, along-strike variations have also become more apparent, so that the profiles across different parts of the Southern Uplands are now seen to be significantly different (e.g. Stone et al. 2012, their figures $15 \mathrm{a} \& \mathrm{~b}$ ). The biostratigraphical control of the along-strike variation has important structural implications, with individual tracts seen to be excised or repeated, and in some cases appearing to be out-of-sequence. Because the terrane built up as a 
southward-propagating and mostly forward-breaking imbricate thrust belt, the initial deformation in each tract followed not long after the deposition of the strata involved. Hence the deformation was systematically diachronous (e.g. Barnes et al. 1989), and changes in the deformational regime can be tracked through time by the graptolite biostratigraphy of the affected rocks.

Refinement of the graptolite biostratigraphy seems likely to continue. In terms of the British Lower Palaeozoic, many of the recent advances have arisen from research in Wales (Zalasiewicz et al. 2009) but work also continues in the Southern Uplands as exemplified by a thematic set of papers - Scottish graptolite biostratigraphy published in 2003 in the Scottish Journal of Geology. In their introduction to the thematic set, Stone et al. (2003a, p. 14) stress that "[a]n understanding of the Southern Uplands accretionary thrust terrane has been achieved only by the integration of work in a range of geological disciplines. Graptolite biostratigraphy remains an essential component of that continuing analysis."

Conodonts were used by Armstrong et al. (1996) to supplement the graptolite biostratigraphy of the Northern Belt and to strengthen correlation with the coeval Midland Valley successions, an important aspect of their fore-arc model. Their interpretation, and the broader regional synthesis by Armstrong \& Owen (2001), was also aided by correlations of the shelly fauna, notably brachiopods. Within the Northern Belt's Kirkcolm Formation the shelly fauna, comprising trilobites, gastropods and corals as well as the brachiopods, is not in situ but is instead, at several localities to the NE of Abington, contained within mass flow deposits interbedded with the sandstone succession (Clarkson et al. 1992). The fauna is of mid-Caradoc age, equivalent in age to in situ shelly faunas known from the southern margin of the Midland Valley Terrane at Girvan (Scotland) and Pomeroy (Northern Ireland). Despite its relative proximity to Girvan, the Kirkcolm Formation fauna compares most closely to that of Pomeroy, a correlation established in particular by an assessment of the brachiopods by Candela \& Harper (2010) who identified 40 different taxa from the Kirkcolm Formation mass-flow deposits. The conclusion drawn was that whilst moderate sinistral displacement of up to a few hundred kilometres along the Southern Upland Fault was quite likely, earlier speculation of very much greater sinistral movement (e.g. Elders 1987) could be discounted. 
In the future, radiolaria may offer some additional biostratigraphic benefit in the Southern Uplands and the results of exploratory work on cherts have been reported by Danelian \& Clarkson (1998) and Danelian \& Floyd (2001). However, the biostratigraphy of Lower Palaeozoic radiolaria is still, for the most part, poorly known and so progress in this area is likely to be slow.

\section{Lithostratigraphy and Provenance}

The oldest rocks known from the Southern Uplands Terrane are the mid-Ordovician, Arenig and Llanvirn mudstones, cherts and basaltic lavas of the Crawford Group. They represent the oceanic substrate on which the deep-marine, black and grey mudstones of the Moffat Shale Group were deposited. The thick, Caradoc to Wenlock turbidite successions that succeed the Moffat Shale are mostly submarine fan deposits with the variable sedimentological characteristics of channels, depositional sheet flows and lobes, overbank deposits and levee complexes; mass flow conglomerates and hemipelagite interbeds are present locally: much detail was provided by Leggett (1980). Stratigraphical variation in the dominant lithofacies, both vertically and lateral, is demonstrated by changes in individual bed thickness and by the range of typical turbidite features that are present: sole structures on bed bases, grading, and cross- and planar-lamination. These features commonly combine into classical Bouma-type sequences but, whilst the assemblages are locally distinctive, it is not possible to erect a regional lithostratigraphy that relies on them exclusively. Instead, the sedimentology is used to supplement the outcrop pattern of the Moffat Shale Group that defines the tract boundary faults. The primary importance of the strikeparallel faults as stratigraphical boundaries has commonly led to the Southern Uplands divisions being referred to as tectonostratigraphic units.

However the stratigraphy is defined, one of the more remarkable aspects of the Southern Uplands Terrane is the along-strike continuity of the component structural tracts of steeply dipping, turbidite lithofacies beds. Some individual tracts can be traced across the full width of the Southern Uplands, from the North Sea coast to the Rhins of Galloway, and thence into the Down-Longford inlier in Ireland, despite cross-strike widths that are generally less than $10 \mathrm{~km}$ and may be as little as 2 or 3 
$\mathrm{km}$. Apart from the age difference between adjacent tracts, as shown in Figure 2, some of them are dominated by sandstones with a distinctive population of detrital grains. This effect is particularly marked in the Ordovician Northern Belt, where sandstones rich in fresh-looking andesitic grains (both mafic mineral and igneous rock fragments) formed the Galdenoch, Portpatrick and Glenlee formations, in contrast to the more mature compositions of the Kirkcolm and Shinnel formations. Hence formal lithostratigraphy was first applied to the Ordovician succession, as summarised and rationalised by Floyd (1996): the Galdenoch and Kirkcolm formations formed the bulk of the Barrhill Group, the Portpatrick, Shinnel and Glenlee formations formed the bulk of the Scaur Group, both groups (together with the more northerly Tappins Group) made up the Leadhills Supergroup (Figures 1 \& 2). Lithostratigraphical discrimination was aided by measurement of magnetic susceptibility, the andesiticrich sandstones showing much higher values than the more mature sandstones (Floyd \& Trench 1989). Thereafter, as more detail of the Silurian succession (Gala, Hawick and Riccarton groups) became known Floyd (2001) was able to extend a formal lithostratigraphy across the whole terrane.

Since the regional syntheses of Floyd $(1996,2001)$ an additional group comprising five formations has been established in the north-eastern part of the Southern Uplands (Figure 1a). This division, the Ettrick Group, was described by Barnes \& Stone (in Stone et al. 2012) but was first utilised for the British Geological Survey (2009) 1:50k map sheets for the Moffat and Ettrick districts (Scotland sheets 16W \& 16E). Its introduction helped resolve the long-standing interpretational difficulty posed by the regional relationship between the Gala and Hawick groups. In the western part of the Southern Uplands the Laurieston Fault forms a relatively well-defined boundary between them (Figure 1), but eastwards the distinction is less clear and is further complicated by additional structural imbrication which has the effect of progressively broadening the Llandovery outcrop (e.g. Akhurst et al. 2001). The traditional solution has been to place the Gala-Hawick boundary at the northern limit of carbonate-rich sandstones thought characteristic of the Hawick Group (e.g. Floyd 2001). By default, the rocks to the north of this line were assigned to the Gala Group, but an early assessment of the British Geological Survey's G-Base regional geochemical (stream sediment) dataset for Southern Scotland (BGS 1993) had identified the Moffat Valley Fault (Figure 1) as a major compositional boundary with an abrupt change across it in 
$\mathrm{Rb} / \mathrm{Sr}$ ratio as a key feature amongst several steep element distribution gradients coincident with the fault (Stone et al. 1993). The strata contained between the Laurieston Fault and the Moffat Valley Fault were largely those forming the eastward-broadening imbricate zone and as such might not have been directly represented farther west, though correlations have been suggested (Figure 2).

Stone \& Evans (2001) referred the strata between the Laurieston and Moffat Valley faults to the Buckholm Formation, adopting lithostratigraphy proposed farther east in the Gala Water area by Kassi \& Weir (1993); older literature had related these strata to a Garnetiferous Group (Walton 1955) although the boundaries are not everywhere consistent. With $\mathrm{Rb} / \mathrm{Sr}$ ratios similar to those of the Hawick Group rather than the Gala Group, but without the Hawick Group's characteristic high carbonate content, the Buckholm Formation was potentially transitional between the two established groups. The more recent work in the Moffat and Ettrick districts resulted in the formalisation of the lithostratigraphy, with the 'transitional' strata assigned to four formations of the newly-defined Ettrick Group based on detailed sedimentology and whole-rock geochemistry (Figure 6) (Barnes \& Stone in Stone et al. 2012). Though largely accommodating strata that had previously been assigned to the Gala Group, at its southern margin some strata are incorporated in the Ettrick Group that had traditionally been placed within the Hawick Group.

Delineation of the Ettrick Group was assisted by an assessment of the G-Base stream sediment geochemistry (Stone \& McMillan 2013), but the regional aspects of this database have also been applied to the Southern Uplands more generally. Stone et al. $(1999,2004)$ identified two element assemblages as being of particular value in tracking geologicallycontrolled changes in sediment composition: the basic-ultrabasic elements ( $\mathrm{Cr}-\mathrm{Ni}-\mathrm{Mg}-\mathrm{V}$ $\mathrm{Ti}$ ), and the feldspar association (Rb-Sr-K-Ba), both of which had potential as lithostratigraphical mapping surrogates. Breward et al. (2011) were able to extend the element distribution patterns seen in the Southern Uplands westward into the DownLongford inlier, Ireland, utilising similar geochemical data acquired there as part of the TELLUS project. However, the direct spatial associations between the patterns of element distribution in stream sediment and changes in the underlying bedrock outcrop do not necessarily mean that the two media have the same compositions. The significances of relative element enhancement or depletion from rock to sediment have been explored by 
Stone et al. (2003b, 2006) and have implications for the variation in host minerals, as detrital sandstone grains, that may originally have contained the elements in question.

An early application of whole rock geochemistry by Duller \& Floyd (1995) characterised different assemblages of cratonic- and volcanic-derived sandstones. The series of box-plots shown in Figure 7a is one example of geochemical variation derived by Barnes (2008) from the Duller \& Floyd database. It is intriguing that in this and other examples the geochemical abundances do not precisely match what might have been predicted from the sandstone petrography. It would seem that much of the whole-rock geochemical variation is cryptic, being embodied within the abundant matrix of the wacke-type sandstones. This conclusion would also have implications for interpretation of the regional geochemical data. It should also be noted that, in Figure 7a, a 'G9' tract (= Gala Group tract 9) has similar MgO abundance to the adjacent Gala Group tracts 7 and 8. In defining a 'Gala 9' tract, Barnes (2008) followed the nomenclature applied on the Rhins of Galloway by McCurry \& Stone (1996) to a tract that had previously been regarded (Stone 1995) as a correlative of the Cairnharrow Formation (Hawick Group). Compositional data such as those illustrated provoked the change, and has further led to the suggestion that 'Gala 9' on the Rhins of Galloway may correlate with part of the Ettrick Group (Barnes \& Stone in Stone et al. 2012).

Utilising REE geochemistry, Williams et al. (1996) focussed on the volcaniclastic contribution to the Southern Uplands sandstones. They reported results that emphasised the apparently juvenile nature of the volcanic detritus at the time of deposition, a character shown most distinctly by the lack of a negative, chondritenormalised Eu anomaly. Tracking that juvenile influence through time was attempted by Stone \& Evans (2001) using Nd isotope data (Figure 7b), with results confirming the Ordovician provenance bipolarity, mature cratonic versus juvenile volcanic, but thereafter suggesting a progressive arc unroofing trend during deposition of the Gala Group, with a resurgence of a juvenile input during deposition of the Hawick and Riccarton groups. It may be significant that sandstone samples that would later be assigned to the Ettrick Group were marked by the reappearance of juvenile material superimposed on the mature end of the arc unroofing series defined by Gala Group data points (Figure 7b). 
These various geochemical investigations had begun to focus on one of the fundamental points at issue between the different evolutionary models for the Southern Uplands Terrane: the provenance of the volcanic detritus characteristic of some Ordovician and older Silurian tracts. Was the volcanic provenance to the north of a fore-arc accretionary prism (McKerrow et al. 1977; Leggett et al. 1979), or was it to the south of a back-arc depositional basin (Morris 1987; Stone et al. 1987). Mineral chemistry showed that the volcanic material in the volcaniclastic formations was mostly derived from calc-alkaline to transitional calc-alkaline to tholeiitic sources (Styles et al. 1989, 1995) that could be accommodated within both models. However, as more palaeocurrent data were accumulated it became clear that for most formations the directions indicated were quite variable (e.g. Stone 1995, figures 12, 15 and 17) and could be explained by deviation of depositional fans into a basin-axial, NE or SW trend, even if the original source was the Laurentian continental margin to the NW. For most of the volcaniclastic formations this undermined the argument that a southern volcanic arc was necessary to explain the palaeocurrent and compositional patterns. The one exception was the Portpatrick Formation, the most extensive of the Ordovician volcanic-rich divisions, for which a fairly consistent pattern emerged of derivation from the south or SW quadrant.

But even accepting a southern arc source for the Portpatrick Formation, was it active contemporaneously with the Late Ordovician sedimentation, as required by the backarc model? When the age of the Portpatrick Formation volcanic detritus was established, that proved not to be the case. Ar-Ar work by Kelley \& Bluck (1989) on rhyolite and andesite clasts suggested that the volcanic source rocks had an age range of about 560-530 Ma and so were Late Neoproterozoic to Early Cambrian rather than Late Ordovician. Kelley and Bluck's results were relatively imprecise, with large errors, but were subsequently vindicated by $\mathrm{U}-\mathrm{Pb}$ dating of detrital zircons by Phillips et al. (2003) who defined zircon population peaks in the Portpatrick Formation sandstone at around $557 \mathrm{Ma}, 613 \mathrm{Ma}$ and $1043 \mathrm{Ma}$. These dates confirmed that the volcanic detritus was not derived from a Late Ordovician arc, but rather from a pre-existing Neoproterozoic to Early Cambrian arc which, Phillips et al. (2003) suggested, could be correlated with volcanism in Avalonian (providing a southern source) rather than in Laurentia. 
Further evidence from detrital zircon populations was provided by Waldron et al. $(2008,2014)$. In the first of these papers data was presented from five of the lithostratigraphic divisions of the Leadhills Supergroup where, within sandstones from the Kirkcolm, Galdenoch, Glenwhargen and Shinnel and Glenlee formations an abundance of Archaean and Proterozoic zircons were related to potential sources within the Laurentian basement. Although no Portpatrick Formation sandstones were analysed, Waldron et al. (2008) were not convinced of the southerly, Avalonian origin for Neoproterozoic zircons that had been proposed by Phillips et al. (2003). Instead, Waldron et al. (2008) felt that the Neoproterozoic zircons could also be accommodated in a Laurentian provenance. Data in support of a Laurentian origin was subsequently presented by Waldron et al. (2014) in a wide-ranging study of detrital zircons from the trans-Iapetus zone in Britain, Ireland and Canada. Taken in conjunction with their earlier paper, Waldron et al. (2014) provided detrital zircon data from the full tectonostratigraphic range of the Southern Uplands Terrane including the Portpatrick Formation, although the Ettrick Group was not differentiated from the Gala Group. The results showed a consistent dominance of Mesoproterozoic zircons in all of the samples, whilst the proportion of Archaean zircon decreased into the younger rocks. Most samples also contained some Cambrian and/or Early Ordovician zircon grains thought to have originated from a combination of Laurentian margin, rift-related and volcanic arc magmatism, or from erosion of obducted ophiolite bodies such as the Ballantrae Complex. These younger zircons apart, Waldron et al. (2014) accommodated their results within an entirely Laurentian provenance, principally by a progressive change in source from the younger parts of the Dalradian succession to a combination of its older divisions and parts of the Moine Supergroup.

Setting aside the volcaniclastic components, the zircon data of Waldron et al. (2008, 2014) was seen as strongly supporting a broadly Dalradian provenance for much of the Southern Uplands 'continental' sediment.

This had been favoured by Hutchison \& Oliver (1998) on the basis of a close similarity between detrital garnet grains from Southern Uplands sandstones (mostly from the Corsewall (Tappins Group) and Kirkcolm formations) and 'Barrovian' metamorphic garnet from the Dalradian (Grampian Terrane). Conversely, an 
assessment of the regional geochemical dataset by Stone et al. (1999) found little evidence to support a Dalradian provenance with, for example, the high Ti levels of the Dalradian not reflected across most of the Southern Uplands (the Kirkcolm Formation excepted). Debate continues as to whether erosion of Dalradian rocks provided the sediment for some Southern Uplands sandstones, or whether these were sourced in a separate Midland Valley Terrane. Kelley \& Bluck (1989) reported Ar-Ar ages in the range $458 \mathrm{Ma}$ to $502 \mathrm{Ma}$ for detrital micas in sandstones from the Kirkcolm and Portpatrick formations. Although these ages were compatible with a derivation of the mica grains from the Dalradian, that possibility was discounted by Kelley and Bluck, largely on palaeogeographical grounds. Their preference was for a provenance sited within the Midland Valley Terrane, where Early Palaeozoic arc magmatism was thought to have been responsible for the uplift of continental basement, allowing its rapid erosion. Bluck (2001) reviewed mica ages then available for the Southern Uplands and the Dalradian and emphasised that the modal age of dates from the detrital micas in the former terrane was some $30 \mathrm{Ma}$ earlier than the modal age from the Dalradian. Radiometric dating of a granite boulder from a Corsewall Formation (Tappins Group) conglomerate (U-Pb monazite: $474 \pm 2 \mathrm{Ma}$ ) was also cited by Bluck et al. (2006) as evidence for a 'Midland Valley arc' provenance for the Southern Uplands sediment, with the palaeogeographical objections to a Dalradian provenance reiterated. Conversely, the Dalradian provenance for Northern Belt sandstones received strong support from a detrital heavy mineral study by Mange et al. (2005) that demonstrated the progressive unroofing and erosion of a Barroviantype metamorphic complex, though unusual components in the Portpatrick Formation again hinted at an Avalonian/Cadomian provenance.

The Midland Valley situation was clarified by results obtained by Phillips et al. (2009) from a study of detrital zircons in sandstones occupying the Silurian inliers along the southern margin of that terrane. Phillips and his co-workers found a paucity of Archaean zircons and demonstrated a bimodal distribution of Mesoproterozoic (ca $1000 \mathrm{Ma}$ ) and Early Ordovician (ca $475 \mathrm{Ma}$ ) ages that together ruled out a Dalradian provenance. If the Southern Uplands sediment had been derived from Dalradian sources within the Grampian Terrane, either it would have had to somehow bypass the Midland Valley Terrane, or those terranes had a very different spatial relationship to that currently seen. Phillips et al. (2009, see especially Figure 8 therein) speculated 
that sequential sinistral strike-slip movements might have resolved this difficulty by juxtaposing different provenance areas and depositional centres at different times.

\section{Structure and deformational progression}

At the heart of Southern Uplands regional structure lies the stratigraphical paradox, wherein at outcrop most of the steeply inclined beds face northward so that the sequence becomes younger in that direction, yet the oldest strata are found in the north of the terrane and the youngest in the south. Various geometries of folding and faulting have been proposed as explanations, with the forerunners to the current, accretionary thrust model summarised by Anderson (2001). Structural summaries (and bibliographies) have also been provided by Barnes \& Stone (1999), Oliver et al. (2002) and Stone et al. (2012).

In terms of the accretionary prism model (and implicit in its rivals), a thrust complex developed above the northward-dipping subduction zone that carried Iapetus Ocean crust beneath the Laurentian continental margin. It was built by a series of southwardpropagating, imbricate thrusts that sequentially stripped the oceanic sedimentary cover from the descending plate and stacked-up the ensuing, fault-bounded tracts, each tract being inserted at the base of a stack of previously accreted tracts (Figure 5). The true picture is probably more complicated, with frontally accreted thrust units riding above one or more décollement levels below which underplated duplex structures developed (Figure 8).

An underplating regime, as described by Sample \& Moore (1987) from the Kodiak complex (Alaska), appears to be the most conducive environment for the accretion of the coherent tracts of strata that characterise the Southern Uplands. In many other accretionary environments there is considerable disruption of the accreting strata to produce an abundance of mélange, but this lithology is generally scarce in the Southern Uplands. Mélange or 'mélange-like' lithologies have been described by Kemp (1987) and Needham (1995) from the Hawick Group, and by Ogawa (1998) from the Tappins Group, but all would be more properly termed 'broken formations' and still represent only a very minor component of the overall accretionary assemblage. 
Prior to the underplating proposals of Sample \& Moore (1987), reasons for the scarcity of mélange were debated by Leggett et al. (1982). They cited work by Moore (1979) which had established that accretion of coherent units of strata was more likely when there was a low ratio of plate convergence rate to sediment influx; a high ratio favoured disruption and mélange formation. This situation - a low convergence rate coupled with a high sedimentation rate - would appear to have prevailed in the Southern Uplands prism where accretion was relatively long-lived and the sediment supply consistently abundant. It would have required at least 20 million years of oceanic subduction to incorporate the tracts now forming the Late Ordovician Leadhills Supergroup and the Early Silurian Gala Group, and perhaps another 10 million years of 'foreland basin convergence' following closure of the ocean to incorporate the tracts of the Ettrick, Hawick and Riccarton groups. It has been widely assumed that its maximum, the Iapetus Ocean was at least $1000 \mathrm{~km}$ wide, a figure supported by an area balancing assessment by Anderson (2001) that calculated a width in excess of $1000 \mathrm{~km}$ for the Moffat Shale depositional basin. Taking from these figures the approximation that $500 \mathrm{~km}$ of oceanic crust were subducted at the Laurentian margin whilst the Southern Uplands accretionary prism developed over 25 million years, it gives a relatively slow subduction rate of about $2 \mathrm{~cm} / \mathrm{year}$, at the lower end of the 2 to $8 \mathrm{~cm} /$ year of convergence generally agreed for currently active subduction zones.

The deformational sequence

Whether involved in frontal accretion or in underplating, the original thrust faults would have advanced at a relatively low angle but, as the complex developed, were structurally rotated towards the vertical, as were the strata between them. This would have occurred progressively, with the older strata (in the north) steeply rotated whilst younger strata (in the south) remained at a shallow angle. Hence it is difficult to envisage the currently uniform arrangement of steeply dipping and locally overturned strata, consistently present across the entire width of the exposed accretionary complex, being created by the accretionary process alone. Much post-accretion shortening and rotation seems probable, as will be discussed below. At depth the 
tract-bounding faults have been generally illustrated as listric, merging northwards into a major regional décollement; again the reality may well be more complicated.

An early phase of deformation $\left(D_{1}\right)$ seen throughout the Southern Uplands is related to thrust propagation, hence the folds produced are diachronous, becoming younger southwards. Later phases of deformation are apparent locally, associated either with accommodation in the thrust hinterland commensurate with $\mathrm{D}_{1}$ deformation at the thrust front (and so likely to be equally diachronous as D1 but less systematically so) or with intermittent sinistral shear imposed across the entire belt but focused into major strike-parallel fault zones. These post- $\mathrm{D}_{1}$ deformation phases have been referred respectively to $D_{2}$ (co-axial with the gently plunging $D_{1}$ folds) and $D_{3}$ (sinistral, steeply plunging folds) following Barnes et al. (1989), but their relationship is not everywhere strictly sequential.

The earliest accreted units that are still preserved form the Tappins Group (Figure 1). They show much evidence of stratal disruption; chaotic bedding is fairly widespread and a scaly cleavage is locally developed (Ogawa 1998). These features were thought by Merriman \& Roberts (2001) to be characteristic of frontal accretion in and above a zone of décollement, and they also noted a cryptic disruption of the sedimentary microfabric by bedding-plane slip. Further south within the Southern Uplands, thrust units containing relatively coherent bedding and a more widely developed slaty cleavage probably passed beneath the décollement and accumulated as a series of underplated thrust duplexes. In the great majority of examples, the thin Moffat Shale Group succession acted as the décollement horizon, allowing the overlying turbidite successions to be stripped from the subducting basement of oceanic crust. Needham (2004) has investigated structures within the décollement zones and described different structural assemblages thought to have arisen from deformation at different depths within the accretionary complex. These may correspond to frontal accretion and underplating or to underplating at different structural levels.

Within the Leadhills Supergroup tracts south of the Tappins Group and those forming the northern (older) part of the Gala Group, the accretion-related folds $\left(D_{1}\right)$ are mostly south-verging (commensurate with south-directed thrusting) with an axial planar cleavage; any superimposed $\mathrm{D}_{2}$ structures tend to be co-axial with the $\mathrm{D}_{1}$ folds and 
may be associated with a crenulation cleavage and locally with minor north-directed thrust movement (e.g. Barnes et al. 1989; Needham 1993). Further south, there is a change in $\mathrm{D}_{1}$ structural style in the southernmost Gala Group that thence carries southward through the Ettrick and Hawick groups. The tract biostratigraphy shows the change in style to have occurred from the Late Llandovery onwards. The sequential southward younging of the structural tracts, established through the Leadhills Supergroup and the northern (older) part of the Gala Group, is replaced in the Ettrick Group by the repetition of narrow tracts all with very similar ages. Through the southernmost Gala Group tracts, increased complexity and asymmetry are apparent in the $\mathrm{D}_{1}$ fold pattern with, for example, north-verging fold and thrust tracts (McCurry \& Anderson 1989; Holdsworth et al. 2002a) and the likelihood of out of sequence thrusting (Rushton et al. 1996; McMillan. 2002).

In general, the Hawick Group tracts are more folded and are affected by a stronger cleavage than is apparent in the older tracts to the north, with a tendency for the cleavage to be clockwise transecting, up to $20^{\circ}$ locally (Stringer \& Treagus 1980; Anderson 1987). The plunge of the fold hinges may be highly variable and folds are downward-facing locally. This combination of structural features indicates that, from the mid-Llandovery onwards, a significant component of sinistral shear was intermittently present during the accretionary $\mathrm{D}_{1}$ deformation at the thrust front, and at the same time was probably responsible for the imposition of the steeply plunging $\mathrm{D}_{3}$ folds within the thrust hinterland. The domainal nature of this transpressive deformation has been stressed, most recently by Holdsworth et al. (2002b) who describe, from the Berwickshire coastal sections, its partitioning into strike-slip and contraction-dominated zones. The approximate temporal coincidence of this increase in transpression affecting the Hawick Group, with back-thrusting and out-of-sequence thrusting affecting the southernmost (youngest) Gala Group tracts, led to the suggestion by Rushton et al. (1996) that during the Late Llandovery the accretionary thrust belt had to accommodate to an obstacle to its forward propagation. This may have been an isolated crustal feature - Novantia of Armstrong \& Owen (2001) or its precedents - or the process might have seen the effective closure of the Iapetus Ocean with the subsequent, youngest Llandovery to Wenlock turbidite successions (Hawick $\&$ Riccarton groups) deposited in a post-collisional basin. Of course, many other variables may also have been influential, perhaps a change in plate convergence 
parameters or in sediment input rate. Whatever the cause, by the time of the Wenlock deposition of the Riccarton Group, the forward-breaking, sequential thrust pattern characteristic of the earlier phase of accretion appears to have been re-established (Kemp 1986).

Overall, it seems likely that the Iapetus Ocean had closed by the Late Wenlock, with deformation of the Hawick-Riccarton successions within a foreland fold and thrust belt that migrating across the sutured remains of the Iapetus Ocean and then southward to over-ride the Avalonian continental margin. Ahead of the deformation front, sedimentary links suggest that by Wenlock times the foreland basin extended to the Isle of Man and into the south of the English Lake District (Kemp 1991, Kneller et al. 1993, McCaffrey \& Kneller 1996; Morris et al. 1999). A particularly clear correlation is provided by a distinctive laminated hemipelagite facies seen in the Ross and Raeberry Castle formations (Hawick and Riccarton groups respectively) in the Southern Uplands, in the Brathay Formation (Windermere Supergroup) in the Lake District, and in the Niarbyl Formation (Dalby Group) in the Isle of Man. By Ludlow times, loading by the advancing Southern Uplands thrust belt had caused an acceleration of subsidence on the Avalonian margin, with deposition of a thick Ludlow turbidite sequence now preserved in the southern Lake District as the Coniston Group of the Windermere Supergroup. Thereafter convergence stalled and the post-Iapetus depocentre had stabilised and filled by the end of Přídolí times.

The Southern Uplands accretionary complex appears not to have suffered any substantial deformation as a result of the Laurentia-Avalonia collision, which accordingly has been widely described as 'soft'. One explanation offered for the lack of deformation is the possibility that final closure of the Iapetus Ocean, as modelled palaeogeographically, was largely effected by sinistral strike-slip tectonics (e.g. Soper et al. 1992b). The widespread evidence of fold-transecting cleavage patterns and vein arrays (e.g. Anderson 1987) demonstrates a degree of sinistral shear within the accretionary complex, as do the steeply-plunging D3 folds. But these are relatively small-scale structures, and evidence for sinistral shear on a larger scale has proved generally elusive. However, one potentially very significant larger-scale structure has been reported recently by Beamish et al. (2010) after analysis of a high-resolution, airborne conductivity survey (part of the TELLUS project) that proved spectacularly 
successful in delineating the thin zones of Moffat Shale Group carbonaceous mudstone in the Down-Longford extension of the Southern Uplands Terrane. Near Banbridge, in County Down, the conductivity data suggested that unexposed (but near-surface) Moffat Shale Group inliers, and by association the strike-parallel, tractboundary faults, define a large sinistral strike-slip duplex. Such cryptic structures might also be present in Scotland, where conductivity data is not available.

Despite the lack of deformation, and arguments in favour of strike-slip tectonics, there is some evidence at the northern margin of the accretionary complex, for its northward emplacement onto Laurentian crystalline basement. North-directed thrusting of the Girvan succession during the mid to late Silurian was demonstrated by Williams (1959) and incorporated into an overall regional structure portrayed by Needham \& Knipe (1986) as a large-scale pop-up. In this model, the Iapetus Suture formed the forethrust, and the backthrust zone now manifest at Girvan was responsible for obducting the rear of the accretionary complex north-westward onto the Laurentian margin. It is tempting to speculate that considerable horizontal shortening of the accretionary complex would have been likely in such circumstances and may have been accommodated by the widespread rotation of bedding towards the vertical, an attitude hard to attain across the whole terrane only by accretionary activity. That said, it is actually difficult to envisage in detail any specific structural mechanism that could produce the unique tectonostratigraphical pattern and uniformly steep dips of the Southern Uplands Terrane.

The last of the 'Caledonian' structural features imposed on the Southern Uplands, subsequent to any D3 reactivation of the strike-parallel faults, was a regional, conjugate set of cross-cutting strike-slip faults. The individual faults have mostly small displacements but are widespread and numerous (e.g. Anderson 1987; Stone 1995); sinistral faults trend NNE-SSW whilst dextral faults trend NW-SE. The cumulative effect of these minor but multiple displacements may be responsible for the local variations in bedding strike seen in some parts of the terrane (Anderson 2001). This fault pattern also played an important role in the post-Silurian tectonic history of the Southern Uplands Terrane by defining the marginal orientations of Devonian and Permo-Carboniferous graben and half-graben basins. 


\section{Moniaive Shear Zone}

A major, regional product of strike-parallel, sinistral transpression is the Moniaive Shear Zone (MSZ), which occupies the northern margin of the Gala Group tract assemblage in the central part of the Southern Uplands (Figure 1b). It is a zone of high strain, up to $5 \mathrm{~km}$ wide, that has been recognised over a strike length of c. $100 \mathrm{~km}$ (Phillips et al. 1995); it continues westward across Ireland as the Slieve Glah Shear Zone. In the Southern Uplands, along most of its length the MSZ is truncated abruptly to the north-west by the Orlock Bridge Fault but dies out southward within the northern tract of the Gala Group. The exception is in the north-east, where the shear zone diverts southwards, away from the Orlock Bridge Fault, before dying out (Figure 1b). It is characterised by the intermittent development of a pervasive foliation accompanied locally by a strong linear component. The shear fabric is commonly subparallel to the relatively weaker $\mathrm{D}_{1}$ cleavage and transposes all original structure. Strain within the shear zone is very variable but a variety of structural indicators consistently show a sinistral sense of shear. The timing of final shear zone development can be established from relationships in the thermal metamorphic aureole of the Early Devonian Cairnsmore of Fleet Pluton. There, cordierite porphyroblasts are deformed by the shear zone foliation, but the foliation is in turn overprinted by biotite hornfelsing and later stages of the thermal metamorphism. These relationships closely constrain the timing of final development for the Moniaive Shear Zone to around $395 \mathrm{Ma}$ (Evans, Appendix 7 in Barnes 2008). Hence the MSZ could have been active during the Acadian deformational event, dated from Northern England at about 397 Ma (e.g. Merriman et al. 1995).

It is likely that the Moniaive Shear Zone is a composite feature, representing progressive but intermittent deformation over a long time period from its initiation during $\mathrm{D}_{1}$ (accretionary) deformation in the Early Silurian until the possibly Acadian effects in the Early to Middle Devonian. Despite the possible long duration of deformation there are no grounds for assuming very large lateral displacement from evidence in Scotland. Substantial movement of several hundred kilomtres has been proposed for the Slieve Glah Shear Zone, along-strike to the west of the MSZ in Ireland (Anderson \& Oliver 1986) but in Scotland, across the MSZ and the adjacent, tract-bounding Orlock Bridge Fault there is no greater biostratigraphical break than is 
seen across the other tract-bounding faults of the Southern Uplands. However, the MSZ does lie above a deep crustal discontinuity (to be discussed below) that may have focused movement during and after the collision of Laurentia and Avalonia, including Acadian reactivation.

\section{Metamorphism and thermal history}

The Southern Uplands strata were subjected to low grades of metamorphism during development of the accretionary complex and its subsequent burial beneath an unconformable covering of younger strata. The relationships seen are most readily explained if a depth-related (burial) pattern of metamorphism was imposed on strata that were already steeply inclined. Grades defined by the crystal thicknesses of white mica (illite crystallinity) in mudstone (Merriman \& Roberts 2001) range from the deep diagenetic zone to the epizone. The prehnite-pumpellyite facies (approximately equivalent to the anchizone) can be proved fairly widely, especially in volcaniclastic sandstones (e.g. Oliver et al. 1984; Kemp et al. 1985). Only locally does the grade rise to epizone, and mostly that is either in the vicinity of intrusions or where cleavage is unusually well developed.

Assuming low to moderate heat-flow $\left(<25^{\circ} \mathrm{C}\right)$, the depth of burial of the Southern Uplands strata would have ranged from about 6 or $7 \mathrm{~km}$, for those rocks now in the deep diagenetic zone, up to about $13 \mathrm{~km}$ for some of the epizonal rocks (Figure 9). Some of this burial depth would have arisen from the likely post-accretionary cover of Devonian sediment but this alone would not have resulted in the metamorphic relationships now preserved. Most significantly, there is no consistent pattern of increasing grade into older strata, which would be expected in normal sedimentary burial, and instead, some of the highest grades (though still mostly anchizonal) are found in the Hawick Group. In a number of cases the metamorphic grade increases sequentially into younger tracts. If the succession had initially acquired a pattern of normal burial metamorphism whereby grade increases into older strata, and had subsequently been imbricated and rotated, older strata would still be expected to show higher grades than younger strata; this is demonstrably not the case. As an additional complication, in places the grade changes abruptly along strike at major cross faults, with lower grade on the downthrow side. These relationships are most readily 
explained if a depth-related pattern of metamorphism was imposed on strata that were already steeply inclined. This would have been achieved after their incorporation in the accretionary complex. Abrupt changes in grade across some of the tract-boundary faults probably arose through post-metamorphic reactivation of those faults.

To explain the geometry of the metamorphic pattern found in the Southern Uplands thrust complex, Merriman \& Roberts (2001) explored the consequences of two levels of accretion, separated by a zone of décollement (Figure 8a). In this they were influenced by the analogy of the Kodiak accretionary complex, as described by Sample \& Moore (1987), whose model is reproduced for comparison in Figure 8b. Southern Uplands strata accreted to the toe of the prism were stacked above the décollement and were probably metamorphosed only in the late diagenetic zone and with only a weak development of the $\mathrm{D}_{1}$ cleavage. Below the décollement, in a region of underplating, strata were accreted in a series of duplexes, were metamorphosed typically in the anchizone, and show a moderate to well-developed slaty cleavage. At both levels, coherent, thrust-enclosed tracts of strata were rotated and buried to produce a syn- $\mathrm{D}_{1}$, depth-dependent pattern of approximately horizontal metamorphic zones that intersect moderately to steeply dipping strata. Present-day moderate dips on some zonal boundary surfaces confirm the post-accretion rotation suggested by the uniformly steep bedding dips (Merriman \& Roberts 2001). Thereafter, intermittent Devonian through to Permian uplift and extension reactivated the then-near-vertical tract boundary faults to juxtapose different levels of the metamorphic sequence. The greatest displacement is seen along parts of the Orlock Bridge Fault, where Ordovician rocks in the Late Diagenetic Zone are juxtaposed against epizonal Silurian rocks in the Moniaive Shear Zone (Figure 9). Even allowing for the effects of tectonic shearing, downthrow to the north may have been as much as $4 \mathrm{~km}$. However, this effect also highlights an outstanding issue arising from the metamorphic interpretations. There would have been movement on any décollement plane within the accretionary prism, such that an age difference would develop between the strata accreted above and below. Yet even at the Orlock Bridge Fault there is no disruption of the biostratigraphic relationships between the tracts, which maintain a pattern of southward younging by small increments despite the abrupt changes in metamorphic grade. 
The very small crystal size and chemical-crystal structure of clay minerals makes them sensitive to the differences in basin thermal histories that characterise different geotectonic settings (Merriman 2002 and references therein). One dimension of the crystal cell structure of the illite-phengite-muscovite clay mineral series, known as the $b$ unit cell dimension and measurable by $x$-ray diffraction, was linked by Guidotti $\&$ Sassi (1986) to pressure-temperature conditions, so providing a means of assessing the thermal conditions of low-grade metamorphism. This afforded to Stone \& Merriman (2004) a means of testing the relative merits of the back arc (extensional) and fore-arc (convergent) depositional basin settings inherent in the different tectonic models for the terrane. A relatively high heat flow would be expected in the extensional setting, a much lower heat flow in the compressional setting, with the clay mineral structures formed therein under low-grade metamorphic conditions varying accordingly.

In his review of mudrock clay mineral assemblages in the British paratectonic Caledonides, Merriman (2002) had shown that the geotectonic setting of Early Palaeozoic basins strongly influenced clay reactions in responses to diagenesis and low-grade metamorphism. The result was a broader range of clay minerals in the extensional basins of Wales, the northern Lake District (Skiddaw Group) and the Isle of Man (Manx Group) when compared to the convergent basin of the southern Lake District (Windermere Supergroup). Southern Uplands data matched that for the convergent basin of the southern Lake District and, importantly, showed no variation across the width of the accretionary complex. This made unlikely any progression from back arc (extensional) to fore-arc (convergent) basin settings across the Southern Uplands. Stone \& Merriman (2004) extended the comparison to the $b$ cell dimensions with results (Figure 10) that they felt effectively eliminated any possibility of an initially extensional, back-arc setting for the Northern Belt of the Southern Uplands, the model proposed by Morris (1987) and Stone et al. (1987). The convergent, accretionary prism model passes the 'thermal history test', as does the foreland basin interpretation of Stone et al. for the southern part of the thrust complex, but there would be little effective differences between that and the leading edge of the accretionary prism migrating onto the Avalonian continental margin, and developing thereafter as a foreland fold and thrust belt. 
The model for the Southern Uplands Northern Belt proposed by Armstrong et al. (1996), which envisaged its deposition within an extensional basin formed on the Laurentian continental margin, also fails the 'thermal history test'. Although the proposed basin developed above thinned continental crust, the necessary eruption within it of volcanic units such as the Downan Point Lava Formation (the northernmost tract of the Tappins Group adjacent to the Ballantrae Complex) and the Bail Hill Volcanic Group (Figure 1a) would argue strongly for an elevated heat flow in an extensional setting. Instead, the 'thermal history test' indicates a low geothermal gradient in a compressional setting. Such a setting is compatible with the accretionary prism model, in which the volcanic edifices are seen as oceanic features that arrive at the subduction trench, extinct and cooled, there to be incorporated into the thrust complex under compressional conditions and with low thermal gradient.

\section{What lies beneath?}

Given its origins at a continental-oceanic plate boundary and subsequent incorporation into a plate collision zone the Southern Uplands Terrane is inevitably allochthonous, with two lines of evidence suggesting that it is now underlain by crystalline, continental crust. The nature of that crust might be illustrated by the xenoliths contained in post-collision dykes and volcanic vents, whilst regional geophysical data are most readily explicable in terms of a continental-type basement.

A study of xenoliths contained in Carboniferous volcanic rocks led Upton et al. (1983) to infer that the Southern Uplands were underlain by a granulite-facies, feldspathic basement. Xenoliths have also been recovered from the widespread lamprophre dykes that were intruded during the Early Devonian. Floyd \& Phillips (1998) and Barnes (2008) report variably foliated dioritic and granodioritic xenoliths in dykes intruded into the Gala and Hawick groups in Galloway. Given the likely deep source of lamprophyre dykes, these xenoliths could well have been derived from continental crust underlying the accretionary complex. Farther to the south-west, in the extension of the Southern Uplands Terrane into Northern Ireland, Anderson \& Oliver (1996) have interpreted xenoliths of mylonitised andesitic rock as having been derived from the partly subducted Avalonian plate. They suggest a source akin to the Borrowdale Volcanic Group of the English Lake District which, by Early Devonian 
times, had been over-ridden by the advancing Southern Uplands thrust belt. Though none of these suggestions can be definitively verified, they do support the allochthoneity of the Southern Uplands Terrane.

From pioneering seismic interpretations (Bamford et al. 1977; Hall et al. 1983) it became clear that not only was crystalline basement present, but that it might be at unexpectedly shallow depths of only a few kilometres. A counter-proposal, that the seismic data might be explained by an increase at depth in the metamorphic grade of the accretionary complex sedimentary rocks (Oliver \& McKerrow 1984) cannot be entirely discounted but is not generally favoured. A number of seismic lines have now traversed the Iapetus Suture Zone and have generally been interpreted in terms of a north-west-dipping, reflective zone projecting to the surface close to the northern coast of the Isle of Man and thence striking north-east beneath northern England. When the seismic results are integrated with regional interpretations of gravity and magnetic data a rather more complicated picture emerges in which potentially Avalonian-type crust is caught up in a compound suture zone that extends well to the north beneath the Southern Uplands Terrane.

This situation is encapsulated in the interpretation of the long wavelength magnetic anomaly over SW Scotland known as the 'Galloway High' and shown in Figure 11, after Kimbell \& Stone (1995; cf. British Geological Survey 2006). Relatively magnetic continental crust beneath the Southern Upland Terrane and the Lake District Terrane of northern England is separated by a zone of less magnetic crust interpreted as sedimentary rock of Avalonian affinity carried to deep structural levels within the Iapetus Suture Zone. The northern margin of the Southern Uplands' magnetic basement coincides, at depth, with the surface trace of the Moniaive Shear Zone (Figure 1b). Kimbell \& Stone acknowledged that the data could also be explained by strong relief on the deep magnetic basement and, indeed, the earlier seismic interpretations modelled such basement relief. However the 'steps' proposed on seismic grounds were not consistent, and did not match those required by interpretations of the gravity and magnetic data. In particular, they did not provide a structural association with the Moniaive Shear Zone, which was regarded as a highlevel effect of the reactivation of the deep basement structure. 
Accepting an association between the MSZ and a deep basement discontinuity, the ca $395 \mathrm{Ma}$ (broadly Acadian), final phase of sinistral shear would apply equally to both. Its coincidence with the intrusion of the granitic plutons of SW Scotland has been related to a regional tectonic regime of transtension in the Early Devonian (Soper \& Woodcock 2003; Brown et al. 2008) and the significance of the MSZ (and so by implication across the deep structural discontinuity) within this regional regime is emphasised by the significant differences in pluton age and composition that have been noted across it (Thirlwall 1988; Stone et al. 1997). The closest spatial association between the deep and surface features occurs in the deepest structural levels exposed in the Galloway Permo-Carboniferous horst, a composite massif underpinned by the Galloway plutons (Stone et al. 1995). Further to the NE the relationship is not so direct. There, the location and shape of the unexposed but geophysically modelled, compound Tweeddale granitic pluton (Lagios \& Hipkin 1979; Stone et al. 1997) are in close spatial association with the surface traces of the Orlock Bridge and Moffat Valley faults (Figure 1). The top surface of the pluton is modelled as lying about $2-3 \mathrm{~km}$ below ground level, and some fault control on the position of intrusion seems probable. In addition, where it approaches the pluton the MSZ narrows and diverts southwards away from the Orlock Bridge Fault (Figure 1b), providing further evidence for interaction of shearing either with the pluton or with its intrusion process.

With the possibility that both intrusion at Tweeddale and regional sinistral shear were polyphase, the overall relationship of shearing to intrusion remains uncertain. However, it does seem clear that emplacement of the Southern Uplands thrust complex as an allochthon onto continental basement was completed by the Early Devonian. If all of the sinistral shear recorded in the MSZ was related to reactivation along the deep basement discontinuity, then emplacement of the allochthon (or at least its northern sector) would need to have been completed by the mid-Silurian. This time-scale would be more readily achieved if the southern part of the Southern Uplands thrust complex was developed in a foreland basin context above Avalonian continental crust following 'soft' closure of the Iapetus Ocean.

Kimbell \& Stone (1995) speculated that the magnetic basement unit beneath the Southern Uplands might represent the 'missing' arc terrane inferred from provenance 
studies and inherent in the back-arc interpretation of the Northern Belt. This was a valid proposal at the time, although even then Kimbell \& Stone preferred the alternative whereby the Southern Uplands magnetic basement unit was a rifted fragment of the Avalonian margin caught up in the hanging wall of the Iapetus Suture. Subsequently, Armstrong \& Owen (2001) identified the magnetic unit with their Novantia arc terrane, as detailed previously. If the xenoliths described previously do indeed represent Southern Uplands 'basement', the location of their host dykes within the Gala and Hawick groups, and to the south of the Orlock Bridge Fault, would suggest that they were derived from the magnetic basement unit, perhaps Novantia.

\section{Concluding discussion: consensus and outstanding issues}

The current consensus views the Southern Uplands Terrane as having originated, from the late Ordovician to the mid-Silurian, as an accretionary thrust prism at the active, northern margin of the Iapetus Ocean during the subduction of that ocean's crust beneath Laurentian continental crust. The later stages of accretion probably took place in a foreland basin setting, following effective closure of the Iapetus Ocean, as the leading edge of the prism migrated onto the Avalonian continental margin. That nearconsensus nevertheless conceals a range of uncertainties, not least of which is the major space problem arising from the current juxtaposition of the Southern Uplands and Midland Valley terranes. This, the 'missing fore-arc' problem has been emphasised by Bluck in a series of contributions (e.g. 1984, 1985, 2001) and underlies the alternative interpretation of the Northern Belt as an essentially fore-arc succession by Armstrong et al. (1996) and Armstrong \& Owen (2001).

The full regional configuration would envisage the 'missing fore-arc' as lying between the accretionary complex and the Midland Valley arc, with the magmatism therein generated above the subduction zone that also drove accretion. The subalkaline to peralkaline geochemistry of the abundant volcanic ash (metabentonite) layers within the Moffat Shale Group (Merriman \& Roberts 1990) (Figure 3) suggests a source within a continental volcanic arc (or extensional back-arc), and the Midland Valley arc would thus seem a likely candidate. Perhaps surprisingly, the available age data does not support such a correlation. The volcanism recorded in the Moffat Shale Group peaked in the Llandovery at around $430 \mathrm{Ma}$, whilst younger metabentonites 
have been recorded within the Hawick Group (Batchelor et al. 2003). These ages are not reflected in the zircon populations from Llandovery and Wenlock sandstones in the Midland Valley, which would have been deposited in a much more proximal situation to the putative arc. Rather, the Midland Valley detrital zircon population is dominated by older, Arenig to Llanvirn magmatism with a peak at about $475 \mathrm{Ma}$. (Phillips et al. 2009). The picture is further complicated by a likely Dalradian provenance for most of the detrital zircons in Southern Uplands sandstones (e.g. Waldron et al. 2008, 2014) in contrast to the situation in the Midland Valley Terrane, where a dearth of detrital Archaean zircon in the Silurian sandstones was thought by Phillips et al. (2009) to make a Dalradian provenance unlikely. Although counter arguments were presented by Waldron et al. (2014) based on stratigraphical variations in the Dalradian detrital zircon populations, this Ordovician to Silurian dilemma is mirrored in the mid-Silurian to Early Devonian by the apparently missing source of Midland Valley conglomerates. These were derived from the south but from a provenance that is not represented within the currently exposed Southern Uplands Terrane, a circumstance established by a wide range of evidence and discussed by, amongst others, Bluck (1983, 1984), Syba (1989), Stone \& Evans (2001) and Phillips et al. (2004). The complications and contradictions arising from these provenance mis-matches between terranes as currently positioned have been widely explored see Bluck (2013) for a recent comprehensive review - but remain unresolved.

One tempting solution to these enigmas of regional correlation is to assume that large scale strike-slip movement has juxtaposed terrane elements that were originally far apart. However, provenance evidence from the Northern Belt of the Southern Uplands makes this unlikely at the terrane boundary. The derived (in sediment mass flows) shelly faunas in the Kirkcolm Formation have relatively locally, in situ correlatives in the Midland Valley Terrane, albeit in Ireland, whilst detrital mineral grains and zircon dating make a Dalradian provenance likely for all of the sandstones of the Southern Uplands Terrane (Clarkson et al. 1992; Hutchinson \& Oliver 1998; Mange et al. 2005; Waldron et al. 2008, 2014 - but for a summary of the contrary view see Bluck 2013). The extension of detrital zircon analysis through the full range of Southern Uplands tectonostratigraphy by Waldron et al. (2014) is a welcome development, but it should also be noted that much of the other detailed provenance work has been concentrated on the Ordovician, Northern Belt of the Southern Uplands (the Leadhills 
Supergroup) where lithostratigraphical differences are most apparent. Extension of those techniques across the Silurian divisions further south, where compositional differences are cryptic, would allow for a more comprehensive regional assessment.

Detailed provenance analysis of that sort requires an accurate knowledge of the internal structure of the Southern Uplands thrust belt, and for that graptolite biostratigraphy seems likely to remain vital. As further refinement of the biozonal scheme is achieved and new fossil discoveries are utilised, it will be possible to improve contrasts and correlations within the tract pattern based on the inliers of Moffat Shale Group, that ideally form the base of each tract's succession, at least for the Ordovician Leadhills Supergroup and the Silurian Gala and Ettrick groups. A means of remotely mapping those inliers has recently been demonstrated, perhaps unexpectedly, as part of the multidisciplinary TELLUS programme in Northern Ireland. There, a high-resolution, airborne conductivity survey proved spectacularly successful in delineating the thin zones of carbonaceous mudstone in the DownLongford extension of the Southern Uplands Terrane, including concealed inliers with no apparent surface exposure (Beamish et al. 2010). It is the lithological character of the Moffat Shale Group that is probably the key to the development of the Southern Upland Terrane's characteristic structure, providing a fissile and highly effective basal décollement plane for accretion of the overlying turbidite strata in the coherent packages now seen.

As an additional influence, the possibility of oblique convergence must be considered, but the structural evidence is more supportive of mostly orthogonal accretion interrupted by intervals of strike-slip. It also seems unlikely that oblique accretion would produce the distinctive cross-strike, time-stratigraphic pattern (Figure 2) that has become the terrane's leitmotif; more excision, duplication and interleaving of tracts would be expected under that circumstance. When disturbance of the sequential tract-incorporation pattern did occur in the late Llandovery (Ettrick and Hawick groups: Rushton et al. 1996), followed by its subsequent re-establishment in the Wenlock (Riccarton Group: Kemp 1986), it most probably marked the effective closure of the Iapetus Ocean and the migration of the accretionary prism onto the Avalonian margin as a foreland fold and thrust belt. 
Figure 12 is an attempt to pull together the evidence for the development of the Southern Uplands Terrane and perhaps to resolve (or at least to highlight) some of the apparent conflicts and difficulties. Such diagrams invariably beg questions of relative scale and have a necessary tendency to exaggerate the portions of particular interest or complexity. Figure 12 is no exception and should be viewed with those limitations in mind.

The Late Ordovician situation shown in Figure 12a has turbidite deposition on an extended fore-arc of thin continental crust. This follows the model developed by Armstrong et al. (1996) and Armstrong \& Owen (2001), for which the rare earth element geochemical evidence from cherts (Owen et al. 1999) seems to provide compelling support. However, this model does throw up some potential difficulties. One issue is a requirement for the same facies of the Glenkiln Shale Formation (Moffat Shale Group) to have been deposited on both the thin continental fore-arc and on the more distant oceanic crust, to be overlain by Late Ordovician turbidites in the former situation but forming the basal sequence of the full Moffat Shale development in the latter. This would seem unlikely and is further complicated by the possibility that a trench may have intervened between the two environments since subduction to generate the Midland Valley magmatic arc would be likely at that time. A second issue is the origin of the volcanic rocks within the Northern Belt succession, most of which have apparently oceanic, within-plate geochemistry. A solution here might lie in the disturbances that would inevitably have accompanied the obduction of the Ballantrae Complex, with the possibility of slab break-off and/or a reversal in subduction direction: for further discussion see Stone (2014). Nevertheless, there remains the difficulty of the apparently low heat flow in the Northern Belt depositional basin at a time of active volcanicity; a problem not addressed in Figure $12 \mathrm{a}$ and which remains unresolved.

The Ballantrae Complex is shown in Figure 12a as an ophiolitic wedge trapped between the Midland Valley volcanic arc (at the margin of Laurentia) and its fore-arc of thin continental crust, represented as two separate continental blocks. If the Ballantrae Complex formed through compression of an arc to back-arc zone formed in such a way, it would obviate the otherwise necessary long-distance obduction of the ophiolite across the fore-arc (Stone 2014). Another important assumption in Figure 
$12 \mathrm{a}$ is the inclusion within the fore-arc crust of the magnetic continental basement unit recognised by Kimbell \& Stone (1995) as the source of the 'Galloway High' (Figure 11), and identified as 'Novantia' by Armstrong \& Owen (2001). The early incorporation of Novantia at the Laurentian margin, perhaps as a part of the processes driving Late Arenig obduction of the Ballantrae Complex ophiolite, would ease the difficulty of subsequently subducting a block of continental crust beneath the Southern Uplands accretionary prism. It might however be seen as unlikely for a periGondwanan fragment (as Novantia was viewed by Kimbell \& Stone (1995) on geophysical grounds) to be accreted onto Laurentia as early as the Arenig.

Towards the end of the Ordovician, the time interval represented in Figure 12b, subduction of Iapetus Ocean crust accompanied a generally compressive regime across the fore-arc region. In response, the thin continental basement blocks became imbricated, and above them a forward-breaking thrust belt developed in the turbidite succession. Turbidite deposition ahead of the thrust belt encroached outward onto Iapetus Ocean crust. It should be noted that initiating the thrust belt above continental crust (Novantia and its inboard companion in Figure 12b) diminishes the scale required for later thrust movement of the entire accretionary prism back onto the margin of Laurentia. By the earliest Silurian, the situation represented in Figure 12c, the fore-arc thrust belt has migrated into the oceanic realm and developed further as a conventional, supra-subduction accretionary prism. But it must be admitted that such a transition without any interruption of the regional tectonostratigraphic pattern (Figure 2) is remarkable, particularly if décollement planes developed within the prism. Meanwhile, that objection notwithstanding, further shortening of the fore-arc basement is envisaged through block rotation and imbrication, and was reflected in the accretionary prism by rotation and steepening of the early-formed tracts. Finally, Figure $12 \mathrm{~d}$ illustrates the possible mid-Silurian situation following the elimination of the Iapetus Ocean by the 'soft' collision of Avalonia and Laurentia. The leading edge of the accretionary prism advanced onto the Avalonian margin, causing the Late Llandovery structural disruptions noted by Rushton et al. (1996) before the forwardbreaking thrust pattern was re-established in a foreland basin setting. Shortening of the fore-arc basement continued and was accompanied by some north-directed thrusting at the rear of the accretionary prism. Strike-slip movement was preferentially partitioned into the basement discontinuities and propagated upwards as 
the Moniaive Shear Zone adjacent to the Orlock Bridge Fault and the Southern Upland Fault (labelled $1 \& 2$ in Figure 12d). Subsequent isostatic rebound of the depressed Avalonian crust would have contributed to subsequent uplift of the whole accretionary complex relative to the Midland Valley Terrane, creating the overall downthrow to the north now seen across the Southern Upland Fault.

So far, so deceptively simple, but in reconstructing idealised cartoons such as those shown in Figure 12, it is easy to forget the true scale of the palaeogeography represented. The Southern Uplands Terrane represents just a small fragment of the Paratectonic Caledonides, which in turn are but the preserved fragments of a vastly more extensive Early Palaeozoic palaeogeography. The westward continuation of the Southern Uplands into Ireland, as the Down-Longford Lower Palaeozoic inlier, is well-established with detailed tract correlation possible across the North Channel (e.g. Barnes et al. 1987). Further afield, regional correlations with Newfoundland are possible (e.g. Colman-Sadd et al. 1992) but also serve to emphasise the scale of the original continental margin to the Iapetus Ocean, with its offshore volcanic arcs and islands. Van Staal et al. (1998) compared the northern margin of the Iapetus Ocean, the eventual focus of the Caledonian-Appalachian Orogen, to situation derived from forward-modelling of the present-day west and south-west Pacific Ocean. They concluded that whilst oceanic elements might broadly preserve along strike coherence for several thousand kilometres, convergent and/or strike slip excision or duplication was highly likely, either during oblique convergence or terminal collision. Against this background the Southern Uplands Terrane stands out as a remarkable, thirtymillion-year record of accretionary geological processes at the Laurentian margin of the Iapetus Ocean, from the Late Ordovician to the Middle Silurian.

\section{Acknowledgements}

The development of a regional geological understanding of the Southern Uplands Terrane has been a collaborative effort drawing on contributions from many individuals. I am indebted to many colleagues in the British Geological Survey, with particular thanks due to Adrian Rushton and Andrew McMillan for their invaluable comments on earlier drafts of this review article. I am also grateful for the many helpful and perceptive suggestions provided by the three referees: Bernard Anderson, 
Brian Bluck and Tim Needham. The quality of the figures is entirely due to the skill of Keith Henderson. The paper is published by permission of the Executive Director, British Geological Survey (NERC).

\section{References}

Akhurst, M.C., McMillan, A.A., Kimbell, G.S., Stone, P. \& Merriman, R.J. 2001. Silurian subduction-related assembly of fault-defined tracts at the Laurieston Fault, Southern Uplands accretionary terrane, Scotland, UK. Transactions of the Royal Society of Edinburgh: Earth Sciences, 91, 435-446.

Anderson, T.B. 1987. The onset and timing of Caledonian sinistral shear in County Down. Journal of the Geological Society, London, 144, 817-825.

Anderson, T.B. 2001. Structural interpretations of the Southern Uplands Terrane. Transactions of the Royal Society of Edinburgh: Earth Sciences, 91, 363-373.

Anderson, T.B. \& Cameron, T.D.J. 1979. A structural profile of Caledonian deformation in Down. ). In Harris, A.L., Holland, C.H. \& Leake, B.E. (eds) The Caledinides of the British Isles - Reviewed. Geological Society, London, Special Publications, 8, 263267.

Anderson, T.B. \& Oliver, G.J.H. 1986. The Orlock Bridge Fault: a major Late Caledonian sinistral fault in the Southern Uplands terrane, British Isles. Transactions of the Royal Society of Edinburgh: Earth Sciences, 77, 203-222.

Anderson, T.B. \& Oliver, G.J.H. 1996. Xenoliths of Iapetus Suture mylonites in County Down lamprophyres, Northern Ireland. Journal of the Geological Society, London, 153, 403-407.

Armstrong, H.A. \& Owen, A.W. 2001. Terrane evolution of the paratectonic Caledonides of northern Britain. Journal of the Geological Society, London, 158, 475486.

Armstrong, H.A., Owen, A.W., Scrutton, C.T., Clarkson, E.N.K. \& Taylor, C.M. 1996. Evolution of the Northern Belt, Southern Uplands: implications for the Southern Uplands controversy. Journal of the Geological Society, London, 153, 197 205.

Bamford, D., Nunn, K., Prodehl, C. \& Jacob, B. 1977. LISPB-III. Upper crustal structure of northern Britain. Journal of the Geological Society, London, 133, 481488 .

Barnes, R.P. 2008. Geology of the Whithorn, Kirkcowan and Wigtown district. Memoir of the British Geological Survey, sheets 2, 4W and 4E (Scotland). 
Barnes, R.P. \& Stone, P. 1999. Trans-Iapetus contrasts in the geological development of southern Scotland (Laurentia) and the Lakesman Terrane (Avalonia). In Woodcock, N.H., Quirk, D.G., Fitches, W.R. and Barnes, R.P. (eds) In sight of the Suture: the Palaeozoic geology of the Isle of Man in its Iapetus Ocean context. Geological Society, London, Special Publications, 160, 307-323.

Barnes, R.P., Anderson, T.B. \& McCurry, J.A. 1987. Along-strike variation in the stratigraphical and structural profile of the Southern Uplands Central Belt in Galloway and Down. Journal of the Geological Society, London, 144, 807-816.

Barnes, R.P., Lintern, B.C. \& Stone, P. 1989. Timing and regional implications of deformation in the Southern Uplands of Scotland. Journal of the Geological Society, London, 146, 905-908.

Batchelor, R.A., Harper, D.A.T. \& Anderson, T.B. 2003. Geochemistry and potential correlation of Silurian (Telychian) metabentonites from Ireland and SW Scotland. Geological Journal, 38, 161-174.

Beamish, D., Kimbell, G.S., Stone, P. \& Anderson, T.B. 2010. Regional conductivity data used to reassess Lower Palaeozoic structure in the Northern Ireland sector of the Southern Uplands - Down - Longford terrane. Journal of the Geological Society, London, 167, 649-657.

Bluck, B.J. 1983. Role of the Midland Valley of Scotland in the Caledonian Orogeny. Transactions of the Royal Society of Edinburgh: Earth Sciences, 74, 119-136.

Bluck, B.J. 1984. Pre-Carboniferous history of the Midland Valley of Scotland. Transactions of the Royal Society of Edinburgh: Earth Sciences, 75, 275-295.

Bluck, B.J. 1985. The Scottish paratectonic Caledonides. Scottish Journal of Geology, 21, 437-464.

Bluck, B.J. 2001. Caledonian and related events in Scotland. Transactions of the Royal Society of Edinburgh: Earth Sciences, 91, 375-404.

Bluck, B.J. 2013. Geotectonic evolution of Midland Scotland from Cambrian to Silurian: a review. Scottish Journal of Geology, 49, 105-116.

Bluck, B.J., Dempster, T.J., Aftalion, M., Haughton, P.D.W. \& Rogers, G. 2006. Geochronology of a granitoid boulder from the Corsewall Formation (Southern Uplands): implications for the evolution of southern Scotland. Scottish Journal of Geology, 42, 29-35.

Breward, N., Stone, P., Flight, D. \& Anderson, T.B. 2011. Regional geochemical comparisons from the Lower Palaeozoic, Southern Uplands-Down-Longford terrane in northern Ireland and Scotland. Scottish Journal of Geology, 47, 33-43.

British Geological Survey. 1993. Regional geochemistry of southern Scotland and part of northern England. British Geological Survey, Keyworth, Nottingham. 
British Geological Survey, 2006. Regional Geophysics of Southern Scotland and Northern England. CD-ROM. British Geological Survey, Keyworth, Nottingham.

British Geological Survey. 2009. Moffat and Ettrick. Scotland. Sheets 16 West and 16 East. Bedrock Geology. 1:50 000. British Geological Survey, Keyworth, Nottingham.

Brown, P.E., Ryan, P.D., Soper, N.J. \& Woodcock, N.H. 2008. The Newer Granite problem revisited: a transtensional origin for the Early Devonian Trans-Suture Suite. Geological Magazine, 145, 235-256.

Candela, Y. \& Harper, D.A.T. 2010. Late Ordovician (Katian) brachiopods from the Southern Uplands of Scotland: biogeographic patterns on the edge of Laurentia. Transactions of the Royal Society of Edinburgh: Earth Sciences, 100, 253-274.

Clarkson, E.N.K. and Upton, B.J.G. 2010. Death of an Ocean - a Geological Borders Ballad. Dunedin Academic Press, Edinburgh, 224 pp.

Clarkson, E.N.K., Harper, D.A.T., Owen, A.W. \& Taylor, C.M. 1992. Ordovician faunas in mass-flow deposits, Southern Scotland. Terra Nova, 4, 245-253.

Cocks, L.R.M. \& Fortey, R.A. 1982. Faunal evidence for oceanic separations in the Palaeozoic of Britain. Journal of the Geological Society, London, 139, 465-478.

Colman-Sadd, S.P., Stone, P., Swinden, H.S. \& Barnes, R.P. 1992. Parallel geological development in the Dunnage Zone of Newfoundland and the Lower Palaeozoic terranes of southern Scotland: an assessment. Transactions of the Royal Society of Edinburgh: Earth Sciences, 83, 571-594.

Craig, G.Y. \& Walton, E.K. 1959. Sequence and structure in the Silurian rocks of Kirkcudbrightshire. Geological Magazine, 96, 209-220.

Danelian, T. \& Clarkson, E.N.K. 1998. Ordovician radiolaria from bedded cherts of the Southern Uplands. Scottish Journal of Geology, 34, 133-137.

Danelian, T. \& Floyd, J.D. 2001. Progress in describing Ordovician siliceous biodiversity from the Southern Uplands (Scotland, UK). Transactions of the Royal Society of Edinburgh: Earth Sciences, 91, 489-498.

Dewey, J.F. 1969. Evolution of the Appalachian/Caledonian orogen. Nature, London, 222, 124-129.

Dewey, J.F. 1971. A model for the Lower Palaeozoic evolution of the southern margin of the early Caledonides of Scotland and Ireland. Scottish Journal of Geology, 7, 219-240.

Duller, P.R. \& Floyd, J.D. 1995. Turbidite geochemistry and provenance studies in the Southern Uplands of Scotland. Geological Magazine, 132, 557-569. 
Elders, C.F. 1987. The provenance of granite boulders in conglomerates of the Northern and Central Belts of the Southern Uplands of Scotland. Journal of the Geological Society, London, 144, 853-863.

Floyd, J.D. 1996. Lithostratigraphy of the Ordovician rocks in the Southern Uplands: Crawford Group, Moffat Shale Group, Leadhills Supergroup. Transactions of the Royal Society of Edinburgh: Earth Sciences, 86, 153-165.

Floyd, J.D. 2001. The Southern Uplands Terrane: a stratigraphical review. Transactions of the Royal Society of Edinburgh: Earth Sciences, 91, 349-362.

Floyd, J.D. \& Phillips, E.R. 1998. Xenoliths of Southern Uplands 'basement?' in a lamprophyre dyke, Central Belt, Glen Luce, SW Scotland. Scottish Journal of Geology, 35, 57-62.

Floyd, J.D. \& Rushton, A.W.A. 1993. Ashgill greywackes in the Southern Uplands of Scotland: an extension of the Ordovician succession in the Northern Belt. Transactions of the Royal Society of Edinburgh: Earth Sciences, 84, 79-85.

Floyd, J.D. \& Trench, A. 1989. Magnetic susceptibility contrasts in Ordovician greywackes of the Southern Uplands of Scotland. Journal of the Geological Society, London, 146, 77-83.

Fyfe, T.B. \& Weir, J.A. 1976. The Ettrick Valley Thrust and the upper limit of the Moffat Shales in Craigmichan Scaurs (Dumfries and Galloway Region: Annandale and Ettrick District). Scottish Journal of Geology, 12, 93-102.

Gradstein, F.M., Ogg, J.G., Schmitz, M.D. \& Ogg, G.M. (eds). 2012. The Geologic Time Scale. Elsevier, Oxford, Amsterdam \& Waltham MA. 489-558.

Guidotti, C.V. \& Sassi, F.P. 1986. Classification and correlation of metamorphic facies series by means of muscovite $b$ data from low-grade metapelites. Neues Jahrbuch für Mineralogie, Abhandlungen, 153, 363-380.

Hall, J., Powell, D.W., Warner, M.R., El-Isa, Z.H.M., Adesanya, O. \& Bluck, B.J. 1983. Seismological evidence for shallow crystalline basement in the Southern Uplands of Scotland. Nature, London, 305, 418-420.

Holdsworth, R.E., Tavernelli, E. \& Clegg, P. 2002a. The nature and regional significance of structures in the Gala Group of the Southern Uplands terrane, Berwickshire coast, southeastern Scotland. Geological Magazine, 139, 707-717.

Holdsworth, R.E., Tavernelli, E., Clegg, P., Pinheiro, R.V.L., Jones, R.R. \& McCaffrey, K.J.W. 2002b. Domainal deformation patterns and strain partitioning during transpression: an example from the Southern Uplands terrane, Scotland. Journal of the Geological Society, London, 159, 401-415.

Hutchison, A.R. \& Oliver, G.J.H. 1998. Garnet provenance studies, juxtaposition of Laurentian marginal terranes and timing of the Grampian Orogeny in Scotland. Journal of the Geological Society, London, 155, 541-550. 
Kassi, A.M. \& Weir, J.A. 1993. Depositional and geotectonic history of the Gala area, eastern Southern Uplands, Scotland. Transactions of the Royal Society of Edinburgh: Earth Sciences, 84, 161-173.

Kelley, S. \& Bluck, B.J. 1989. Detrital mineral ages from the Southern Uplands using 40Ar-39Ar laser probe. Journal of the Geological Society, London, 146, 401-403.

Kelling, G. 1961. The stratigraphy and structure of the Ordovician rocks of the Rhinns of Galloway. Quarterly Journal of the Geological Society, London, 117, 37-75.

Kelling, G. 2001. Southern Uplands geology: an historical perspective. Transactions of the Royal Society of Edinburgh: Earth Sciences, 91, 323-339.

Kemp, A.E.S. 1986. Tectonostratigraphy of the Southern Belt of the Southern Uplands. Scottish Journal of Geology, 22, 241-256.

Kemp, A.E.S. 1987. Tectonic development of the Southern Belt of the Southern Uplands accretionary complex. Journal of the Geological Society, London, 144, 827-838.

Kemp, A.E.S. 1991. Mid Silurian pelagic and hemipelagic sedimentation and palaeoceanography. In Bassett, M.G., Lane, P.D. \& Edwards, D. (eds) The Murchison Symposium. Proceedings of an international conference on the Silurian System. Special Papers in Palaeontology, 44, 261-299.

Kemp, A.E.S., Oliver, G.J.H. \& Baldwin, J.R. 1985. Low-grade metamorphism and accretion tectonics: Southern Uplands terrain, Scotland. Mineralogical Magazine, 49, 335344.

Kimbell, G.S. \& Stone, P. 1995. Crustal magnetisation variations across the Iapetus Suture Zone. Geological Magazine, 132, 599-609.

Kneller, B.C., King, L.M. \& Bell, A.M. 1993. Foreland basin development and tectonics on the northwest margin of eastern Avalonia. Geological Magazine, 130, 691-697.

Kuenen, P.H. 1953. Graded bedding, with observations on Lower Palaeozoic rocks of Britain: Part 2, Probable deep-water origin of some Southern Upland rocks. Verhandelingen der Koninklijke Nederlandsche Akademie van Wetenschappen, Afdeeling Natuurkunde Eerste Reeks, 20, Number 3, 36-45.

Lagios, E. \& Hipkin, R.G. 1979. The Tweeddale Granite-a newly discovered batholith in the Southern Uplands. Nature, London, 280, 672-675.

Lapworth, C. 1872. Note on the Results of some Recent Researches among the Graptolitic Black Shales of the South of Scotland. Geological Magazine, 9, 533-535.

Lapworth, C. 1878. The Moffat Series. Quarterly Journal of the Geological Society, London, 34, 240-346, plates 11-13. 
Leggett, J.K. 1980. The sedimentological evolution of a Lower Palaeozoic accretionary fore-arc in the Southern Uplands of Scotland. Sedimentology, 27, 401417.

Leggett, J.K. 1987. The Southern Uplands as an accretionary prism: the importance of analogues in reconstructing palaeogeography. Journal of the Geological Society, London, 144, 737-752.

Leggett, J.K., McKerrow, W.S. \& Eales, M.H. 1979. The Southern Uplands of Scotland: a Lower Palaeozoic accretionary prism. Journal of the Geological Society, London, 136, 755-770.

Leggett, J.K., McKerrow, W.S. \& Casey, D.M. 1982. The anatomy of a Lower Palaeozoic accretionary forearc: the Southern Uplands of Scotland. In Leggett, J.K. (ed.) Trench and Forearc Geology. Special Publications, Geological Society, London, 10, 495-520.

Leggett, J.K., McKerrow, W.S. \& Soper, N.J. 1983. A Model for the Crustal Evolution of Southern Scotland. Tectonics, 2, 187-210.

Mange, M.A., Dewey, J.F. \& Floyd, J.D. 2005. The origin, evolution and provenance of the Northern Belt (Ordovician) of the Southern Uplands Terrane, Scotland: a heavy mineral perspective. Proceedings of the Geologists' Association, 116, 251-280.

McCaffrey, W. D. \& Kneller. 1996. Silurian turbidite provenance on the northern Avalonia margin. Journal of the Geological Society, London, 153, 437-450.

McCurry, J.A. \& Anderson, T.B. 1989. Landward vergence in the lower Palaeozoic, Southern Uplands-Down-Longford terrane. Geology, 17, 630-633.

McCurry, J.A. \& Stone, P. 1996. Excursion 15, Rhins of Galloway. In Stone, P. (ed.) Geology in south-west Scotland: an excursion guide. British Geological Survey, Keyworth, Nottingham, 121-139.

McKerrow, W.S. 1987. The Southern Uplands Controversy. Journal of the Geological Society, London, 144, 735-736.

McKerrow, W.S., Leggett, J.K. \& Eales, M.H. 1977. Imbricate thrust model of the Southern Uplands of Scotland. Nature, London, 267, 237-239.

McMillan, A.A. 2002. Geology of the New Galloway and Thornhill district. Memoir of the British Geological Survey, sheets 9W and 9E (Scotland).

Merriman, R.J. 2002. Contrasting clay mineral assemblages in British Lower Palaeozoic slate belts: the influence of geotectonic setting. Clay Minerals, 37, 207219.

Merriman, R.J., Rex, D.C., Soper, N.J. \& Peacor, D.R. 1995. The age of Acadian cleavage in northern England, UK: K-Ar and TEM analysis of a Silurian metabentonite. Proceedings of the Yorkshire Geological Society, 50, 255-65. 
Merriman, R.J. \& Roberts, B. 1990. Metabentonites in the Moffat Shale Group, Southern Uplands of Scotland: Geochemical evidence of ensialic marginal basin volcanism. Geological Magazine, 127, 259-271.

Merriman, R.J. \& Roberts, B. 2001. Low-grade metamorphism in the Scottish Southern Uplands terrane: deciphering the patterns of accretionary burial, shearing and cryptic aureoles. Transactions of the Royal Society of Edinburgh: Earth Sciences, 91, 521537.

Mitchell, A.H.G. \& McKerrow, W.S. 1975. Analogous evolution of the Burma orogen and the Scottish Caledonides. Bulletin of the Geological Society of America, 86, 305-315.

Moore, J.C. 1979. Variation in strain and strain rate during underthrusting of trench deposits. Geology, 7, 185-188.

Morris, J.H. 1987. The Northern Belt of the Longford-Down Inlier, Ireland and Southern Uplands, Scotland: an Ordovician back-arc basin. Journal of the Geological Society, London, 144, 773-786.

Morris, J.H., Woodcock, N.H. \& Howe, M.P.A. 1999. The Silurian succession of the Isle of Man: the late Wenlock Niarbyl Formation, Dalby Group. In Woodcock, N.H., Quirk, D.G., Fitches, W.R. and Barnes, R.P. (eds) In sight of the Suture: the Palaeozoic geology of the Isle of Man in its Iapetus Ocean context. Geological Society, London, Special Publications, 160, 189-211.

Murphy, F.C. \& Hutton, D.H.W. 1986. Is the Southern Uplands really an accretionary prism? Geology, 14, 354-357.

Needham, D.T. 1993. The structure of the western part of the Southern Uplands of Scotland. Journal of the Geological Society, London, 150, 341-354.

Needham, D.T. 1995. Mechanisms of mélange formation: examples from SW Japan and southern Scotland. Journal of Structural Geology, 17, 971-985.

Needham, D.T. 2004. Deformation in Moffat Shale detachment zones in the western part of the Scottish Southern Uplands. Geological Magazine, 141, 441-453.

Needham, D.T. \& Knipe, R.J. 1986. Accretion- and collision-related deformation in the Southern Uplands accretionary wedge, southwestern Scotland. Geology, 14, 303306.

Ogawa, Y. 1998. Tectonostratigraphy of the Glen App area, Southern Uplands, Scotland: anatomy of an Ordovician accretionary complex. Journal of the Geological Society, London. 155, 651-662.

Oliver, G.J.H. \& McKerrow, W.S. 1984. Seismological evidence for shallow basement in the Southern Uplands. Nature, London. 309, 89-90. 
Oliver, G.J.H., Smellie, J.L., Thomas, L.J., Casey, D.M., Kemp, A.E.S., Evans, L.J., Baldwin, J.R. \& Hepworth, B.C. 1984. Early Palaeozoic metamorphic history of the Midland Valley, Southern Uplands-Longford-Down massif and the Lake District, British Isles. Transactions of the Royal Society of Edinburgh: Earth Sciences, 75, 245-258.

Oliver, G.J.H., Stone, P. \& Bluck, B.J. 2002. The Ballantrae Complex and Southern Uplands terrane. In Trewin, N.H. (ed.) The Geology of Scotland. The Geological Society, London, 167-200.

Owen, A.W., Armstrong, H.A. \& Floyd, J.D. 1999. Rare earth element geochemistry of Upper Ordovician cherts from the Southern Uplands of Scotland. Journal of the Geological Society, London. 156, 191-204.

Peach, B.N \& Horne, J. 1899. The Silurian Rocks of Britain. Volume 1. Scotland. Memoirs of the Geological Survey of the United Kingdom, HMSO, Glasgow, 749 pp.

Phillips, E.R., Barnes, R.P., Boland, M.P., Fortey, N.J. \& McMillan, A.A. 1995. The Moniaive Shear Zone: a major zone of sinistral strike-slip deformation in the Southern Uplands of Scotland. Scottish Journal of Geology, 31, 139-149.

Phillips, E.R, Smith, R.A, \& Floyd, J.D. 1999. The Bail Hill Volcanic Group: alkaline within-plate volcanism during Ordovician sedimentation in the Southern Uplands, Scotland. Transactions of the Royal Society of Edinburgh: Earth Sciences, 89, 233247.

Phillips, E.R., Evans, J.A., Stone, P., Horstwood, M.S.A., Floyd, J.D., Smith, R.A., Akhurst, M.C. \& Barron, H.F. 2003. Detrital Avalonian zircons in the Laurentian Southern Uplands terrane, Scotland. Geology, 31, 625-628.

Phillips, E.R., Barron, H.F., Smith, R.A. \& Arkley, S. 2004. Composition and provenance of the Silurian to Devonian sandstone sequences of the Southern Midland Valley. Scottish Journal of Geology, 40, 23-42.

Phillips. E.R., Smith, R.A., Stone, P., Horstwood, M. \& Pashley, V. 2009. Zircon age constraints on the provenance of Llandovery to Wenlock sandstones from the Midland Valley terrane of the Scottish Caledonides. Scottish Journal of Geology, 45, 131-146.

Rushton, A.W.A. 2001. The use of graptolites in the stratigraphy of the Southern Uplands: Peach's legacy. Transactions of the Royal Society of Edinburgh: Earth Sciences, 91, 341-347.

Rushton, A.W.A., Stone, P. \& Hughes, R.A. 1996. Biostratigraphical control of thrust models for the Southern Uplands of Scotland. Transactions of the Royal Society of Edinburgh: Earth Sciences, 86, 137-152.

Sample, J.C. \& Moore, J.C. 1987. Structural style and kinematics of an underplated slate belt, Kodiak and adjacent islands, Alaska. Geological Society of America Bulletin, 99, 7-20. 
Smith, R.A., Phillips, E.R., Floyd, J.D., Barron, H.F. \& Pickett, E.A. 2001. The Northern Belt 100 years on: a revised model of the Ordovician tracts near Leadhills, Scotland. Transactions of the Royal Society of Edinburgh: Earth Sciences, 91, 421-434.

Soper, N.J. \& Woodcock, N.H. 2003. The lost Lower Old Red Sandstone of England and Wales: a record of post-Iapetan flexure or Early Devonian transtension? Geological Magazine, 140, 627-647.

Soper, N.J., England, R.W., Snyder, D.B. \& Ryan, P.D. 1992a. The Iapetus suture zone in England, Scotland and eastern Ireland: a reconciliation of geological deep seismic data. Journal of the Geological Society, London, 149, 697-700.

Soper, N.J., Strachan, R.A., Holdsworth, R. E., Gayer, R.A. \& Greiling, R.O. 1992b. Sinistral transpression and the Silurian closure of Iapetus. Journal of the Geological Society, London, 149, 871-880.

Stone, P. 1995. Geology of the Rhins of Galloway district. Memoir of the British Geological Survey, sheets 1 and 3 (Scotland). 102 pp.

Stone, P. 2014. A review of geological origins and relationships in the Ballantrae Complex, SW Scotland. Scottish Journal of Geology, 50, 1-25.

Stone, P. \& Evans, J.A. 2001. Silurian provenance variation in the Southern Uplands terrane, Scotland, assessed using neodymium isotopes and linked with regional tectonic development. Transactions of the Royal Society of Edinburgh: Earth Sciences, 91, 447455 .

Stone, P. \& McMillan, A.A. 2013. Regional geochemical patterns in SE Scotland: source lithology, inheritance and glacial overprinting. Scottish Journal of Geology, 49, 33-40.

Stone, P. \& Merriman, R.J. 2004. Basin thermal history favours an accretionary origin for the Southern Uplands terrane, Scottish Caledonides. Journal of the Geological Society, London, 161, 829-836.

Stone, P., Floyd, J.D., Barnes, R.P. \& Lintern, B.C. 1987. A sequential back-arc and foreland basin thrust duplex model for the Southern Uplands of Scotland. Journal of the Geological Society, London, 144, 753-764.

Stone, P., Green, P.M., Lintern, B.C., Simpson, P.R. \& Plant, J.A. 1993. Regional geochemical variation across the Iapetus Suture zone: tectonic implications. Scottish Journal of Geology, 29, 113-121.

Stone, P., Cook, J.M., McDermott, C., Robinson, J.J. \& Simpson, P.R. 1995. Lithostratigraphic and structural controls on the distribution of As and $\mathrm{Au}$ in the SW Southern Uplands, Scotland. Transactions of the Institution of Mining and Metallurgy. (Section B, Applied Earth Sciences), 104, 111-119. 
Stone, P., Kimbell, G.S. \& Henney, P.J. 1997. Basement control on the location of strikeslip shear in the Southern Uplands of Scotland. Journal of the Geological Society, London, 154, 141-144.

Stone, P., Plant, J.A., Mendum, J.R. \& Green, P.M. 1999. A regional geochemical assessment of some terrane relationships in the British Caledonides. Scottish Journal of Geology, 35, 145-156.

Stone, P., Rigby, S. \& Floyd, J.D. 2003a. Advances in Scottish graptolite biostratigraphy: an introduction. Scottish Journal of Geology, 39, 11-15.

Stone, P., Breward, N. \& Merriman, R.J. 2003b. Mineralogical controls on metal distribution in stream sediment derived from the Caledonides of the Scottish Southern Uplands and English Lake District. Mineralogical Magazine, 67, 325-338.

Stone, P., Breward, N., Merriman, R.J. \& Plant, J. A. 2004. Regional geochemistry of cryptic geology: variations in trace element distribution across the Southern Uplands terrane, Scotland. Applied Earth Science (Transactions of the Institution of Mining and Metallurgy B), 113, B43-B57.

Stone, P., Breward, N., Merriman, R.J. \& Barnes, R.P. 2006. The interpretation and application of regional geochemistry: lessons from the Paratectonic Caledonides. Scottish Journal of Geology, 42, 65-76.

Stone, P., McMillan, A.A., Floyd, J.D., Barnes, R.P. \& Phillips, E.R. 2012. British Regional Geology: South of Scotland (Fourth edition). British Geological Survey, Keyworth, Nottingham, $247 \mathrm{pp}$.

Stringer, P. \& Treagus, J.E. 1980. Non-axial planar S1 cleavage in the Hawick Rocks of the Galloway area, Southern Uplands, Scotland. Journal of Structural Geology, 2, 317331.

Styles, M.T., Stone, P. \& Floyd, J.D. 1989. Arc detritus in the Southern Uplands: mineralogical characterization of a "missing" terrane. Journal of the Geological Society, London, 146, 397-400.

Styles, M.T., Perez Alvarez, M. \& Floyd, J.D. 1995. Pyroxenous greywackes in Southern Uplands of Scotland and their petrotectonic implications. Geological Magazine, 132, 539-547.

Syba, E. 1989. The sedimentation and provenance of the Greywacke Conglomerate, Southern Midland Valley, Scotland. PhD thesis, University of Glasgow.

Thirlwall, M.F. 1988. Geochronology of late Caledonian magmatism in Northern Britain. Journal of the Geological Society of London. 145, 951-967.

Toghill, P. 1970. The south-east limit of the Moffat Shales in the upper Ettrick Valley region, Selkirkshire. Scottish Journal of Geology, 6, 233-242.

Tucker, R.D, Krogh, T.E, Ross, R.J. \& Williams S.H. 1990. Time-scale calibration by high-precision $\mathrm{U}-\mathrm{Pb}$ zircon dating of interstratified volcanic ashes in the Ordovician 
and Lower Silurian stratotypes of Britain. Earth and Planetary Science Letters, 100, 51-58.

Upton, B.J.G., Aspen, P. \& Chapman, N.A. 1983. The upper mantle and deep crust beneath the British Isles: evidence from inclusions in volcanic rocks. Journal of the Geological Society, London, 140, 105-121.

Van Staal, C.R., Dewey, J.F., Mac Niocaill, C. \& McKerrow, W.S. 1998. The Cambrian-Silurian tectonic evolution of the northern Appalachians and British Caledonides: history of a complex, west and southwest Pacific-type segment of Iapetus. In Blundell, D.J. \& Scott, A.C. (eds) Lyell: the Past is the Key to the Present. Geological Society, London, Special Publications, 143, 199-242.

Waldron, J.W.F., Floyd, J.D., Simonetti, A. \& Heaman, L.M. 2008. Ancient Laurentian detrital zircon in the closing Iapetus Ocean, Southern Uplands Terrane, Scotland. Geology, 36, 527-530.

Waldron, J.W.F., Schofield, D.I., Dufrane, A., Floyd, J.D., Crowley, Q.G., Simonetti, A., Dokken, R.J. \& Pothier, H.D. 2014. Ganderia-Laurentia collision in the Caledonides of Great Britain and Ireland. Journal of the Geological Society, London, 171, 555-569.

Walton, E.K. 1955. Silurian greywackes in Peebleshire. Proceedings of the Royal Society of Edinburgh, B65, 327-357.

Walton, E.K. 1963. Sedimentation and structure in the Southern Uplands. In: Johnson, M.R.W. \& Stewart, F.H. (eds) The British Caledonides. Oliver \& Boyd, Edinburgh \& London. 71-97.

Williams, A. 1959. A structural history of the Girvan district of south-west Ayrshire. Transactions of the Royal Society of Edinburgh, 63, 629-667.

Williams, A. 1962. The Barr and Lower Ardmillan Series (Caradoc) of the Girvan district of south-west Ayrshire, with descriptions of the brachiopoda. Geological Society, London, Memoir, 3, 267 pp.

Williams, S.H. 1988. Dob's Linn - the Ordovician-Silurian boundary stratotype. In Cocks, L.R.M. \& Rickards, R.B. (eds) A global analysis of the Ordovician-Silurian boundary. Bulletin of the British Museum (Natural History) Geology, 43, 17-30.

Williams, T.M., Henney, P.J., Stone, P. \& Lintern, B.C. 1996. Rare earth element geochemistry of Lower Palaeozoic turbidites in the British trans-Iapetus zone: provenance patterns and basin evolution. Scottish Journal of Geology, 32, 1-8.

Wilson, J.T. 1966. Did the Atlantic close and then re-open? Nature, London, 211, 676-681.

Zalasiewicz, J.A., Taylor, L., Rushton, A.W.A., Loydell, D.K., Rickards, R.B. \& Williams, M. 2009. Graptolites in British stratigraphy. Geological Magazine, 146, 785-850. 


\section{Figure Captions}

Figure 1.

Outline geological maps of the Southern Uplands Terrane showing, in particular: a) the distribution of the lithostratigraphical groups and the position of the named strikeparallel faults that form their boundaries; b) the arrangement of the tectonostratigraphical tracts after Stone et al. (2012, figure 14). For chronostratigraphical correlations see Figure 2. The position of the concealed Tweeddale pluton has been extrapolated from regional gravity data after Stone et al. (2012, figure 28).

Figure 2.

A time (biostratigraphy) versus structural position (tectonostratigraphy) profile for the SW part of the Southern Uplands Terrane, after Stone et al. (2012, figure 15b). Time scale from Gradstein et al. (2012).

Figure 3.

The stratigraphy of the Moffat Shale Group at Dob's Linn showing the distribution and abundance of metabentonites. After Merriman \& Roberts (1990) and Tucker et al (1990).

Figure 4.

Structural cross-sections of the upper Ettrick Water valley to the NE of Moffat: a) the tight folding interpretation of Peach \& Horne (1899, figure 18) - but note the reverse fault at F; b) the imbricate thrust interpretation of Fyfe \& Weir (1976, figure 3). In all cases, the strata succeeding the Moffat Shale Group that was assigned by the authors to the Gala Group would now be regarded as part of the Ettrick Group following British Geological Survey (2009).

Figure 5. 
Representations of the Southern Uplands Terrane as an accretionary prism: a) the original proposal after McKerrow et al. (1977, figure 3); b) a later representation after Stone (1995, figure 3).

Figure 6.

Geochemical differentiation of the Gala, Ettrick and Hawick groups with their component sandstones compositionally separated by $\mathrm{Ni}-\mathrm{Sr}$ and $\mathrm{CaO}-\mathrm{SiO}_{2}$ abundances: after Barnes \& Stone in Stone et al. (2012, figure 20).

Figure 7.

Two examples of geochemical discrimination diagrams that have been used to differentiate the tectonostratigraphy of the Southern Uplands Terrane: a) box plots showing relative $\mathrm{MgO}$ abundance after Barnes (2008, figure 21) utilising data from Duller \& Floyd (1995); b) variation in provenance maturity based on $\varepsilon N d$ values after Stone \& Evans (2001, figure 2). For explanation of abbreviations see Figure 2; the status of 'Gala 9' (G9 in figure 7a) is discussed in the text.

Figure 8 .

Frontal accretion, underplating and burial metamorphism. a) An attempt to integrate structural and metamorphic patterns in a two-layer Southern Uplands accretionary prism utilising a modified Figure 5b, after Stone \& Merriman (2004, figure 2). Lowest grade rocks are accreted at the toe of the prism, rotated and stacked above a major décollement; higher grade rocks are rotated and underplated below the décollement. Syntectonic burial generates a depth-dependent pattern of horizontal metamorphic zones intersecting the steeply dipping strata. b) The accretionary model developed from the Kodiak complex by Sample \& Moore (1987, figure 3).

Figure 9

A NW-SE metamorphic cross-section of the Southern Uplands Terrane through Moniaive, after Merriman \& Roberts (2001, figure 5). For explanation of abbreviations see Figure 2 .

Figure 10 
Histograms of K-white mica $b$ cell dimension data from mudrock lithologies of the Southern Uplands Terrane and comparative areas, after Stone \& Merriman (2004, figure 3) who list details of the data sources.

Figure 11

A model to explain the observed (total field) magnetic anomalies along a NW-SE profile through the SW part of the Southern Uplands Terrane. Shaded units are magnetic, with magnetizations in A/m indicated. After Kimbell \& Stone (1995, figure $3 b)$.

Figure 12

A series of naïve, 2-D cartoons that attempt to demonstrate the relationship of the events that constructed the Southern Uplands accretionary complex as the Iapetus Ocean was subducted beneath the continental margin of Laurentia. The sections are schematic and no relative scale is implied.

\section{Captions for Supplementary Figures}

Supplementary figure 1

Outline geology of Southern Scotland after Stone et al. (2012, figure 2).

Supplementary figure 2

The principal structural tracts of the Southern Uplands Terrane after Stone et al. (2012, figure 14). 


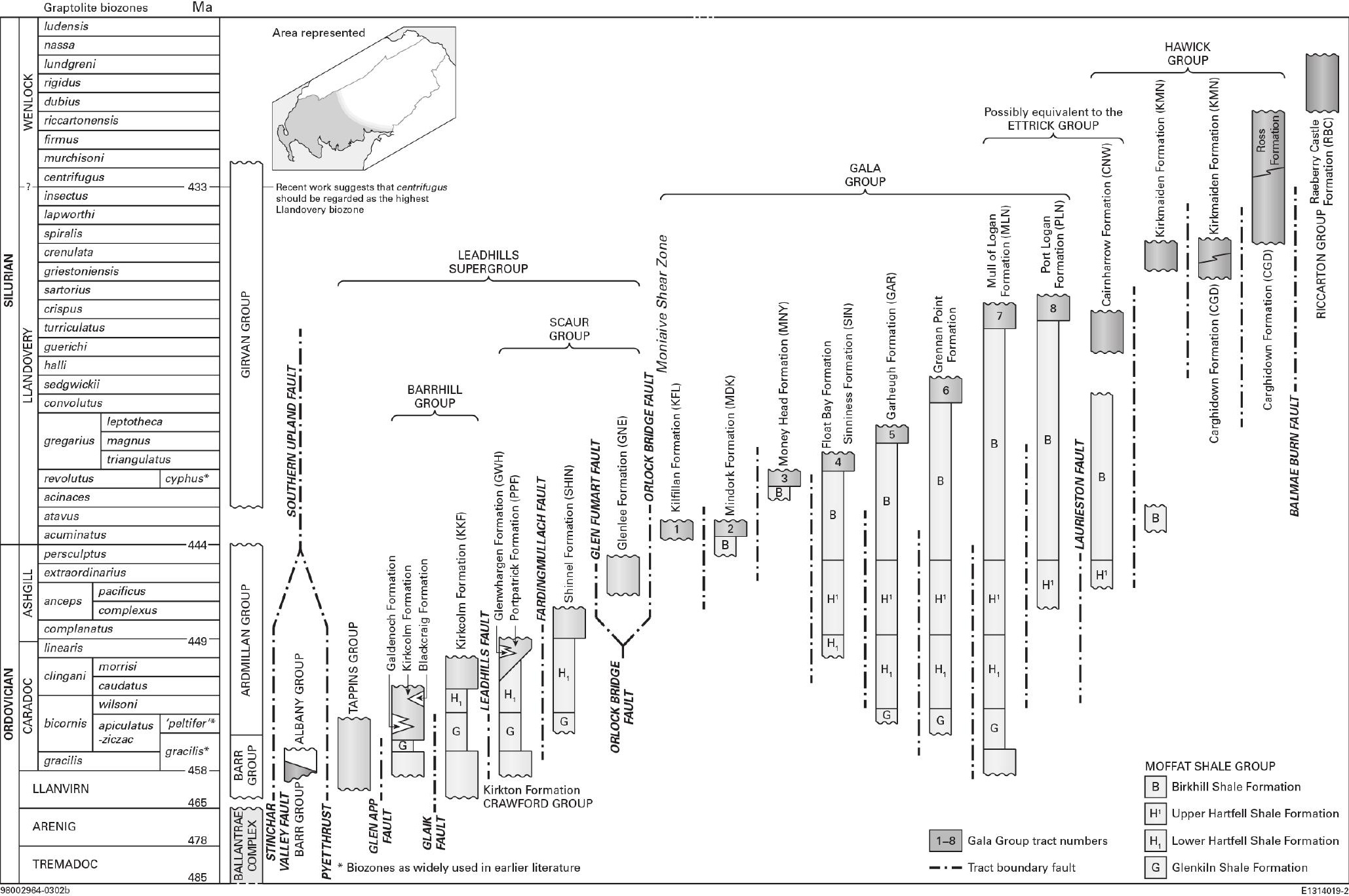


Graptolite biozones Queensberry Formation

sedgwickii

convolutus

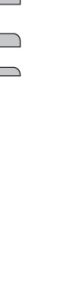

438.7

$\pm 2.0 \mathrm{Ma}$

445.7

$\pm 2.4 \mathrm{Ma}$
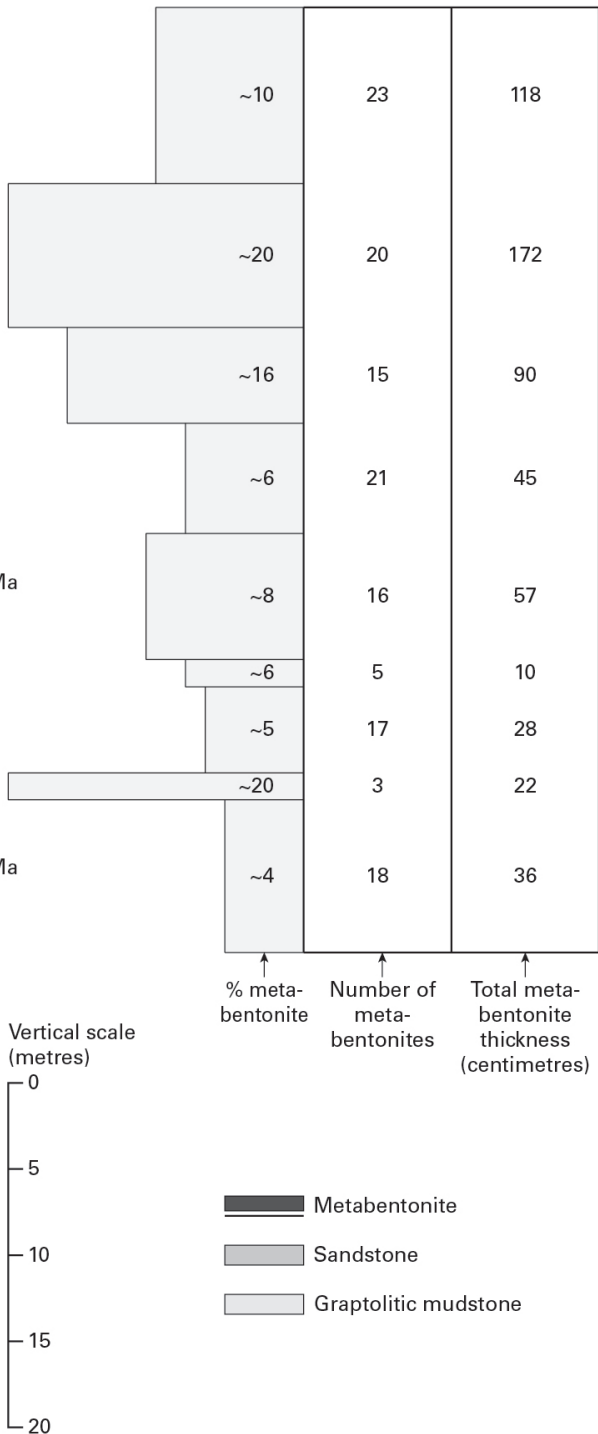

Metabentonite

Sandstone

Graptolitic mudstone

\section{bicornis}


a

Ettrick Pen

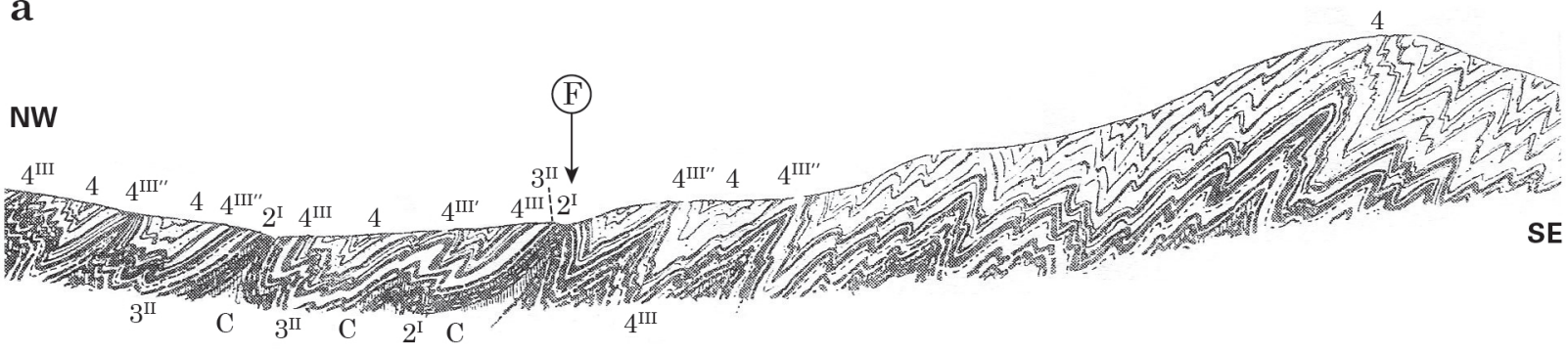

Glenkiln chert. $\quad 2^{\mathrm{I}}$ Glenkiln Shales. $\quad 3^{\mathrm{II}}$ Lower Hartfell Shales.

$4^{\mathrm{II \prime}}$ Upper Birkhill Shales. $\quad 4^{\mathrm{II}}$ R. maximus-zone.
$4^{\mathrm{III}}$ Lower Birkhill Shales.

4. Tarannon series. C. Radiolarian chert.
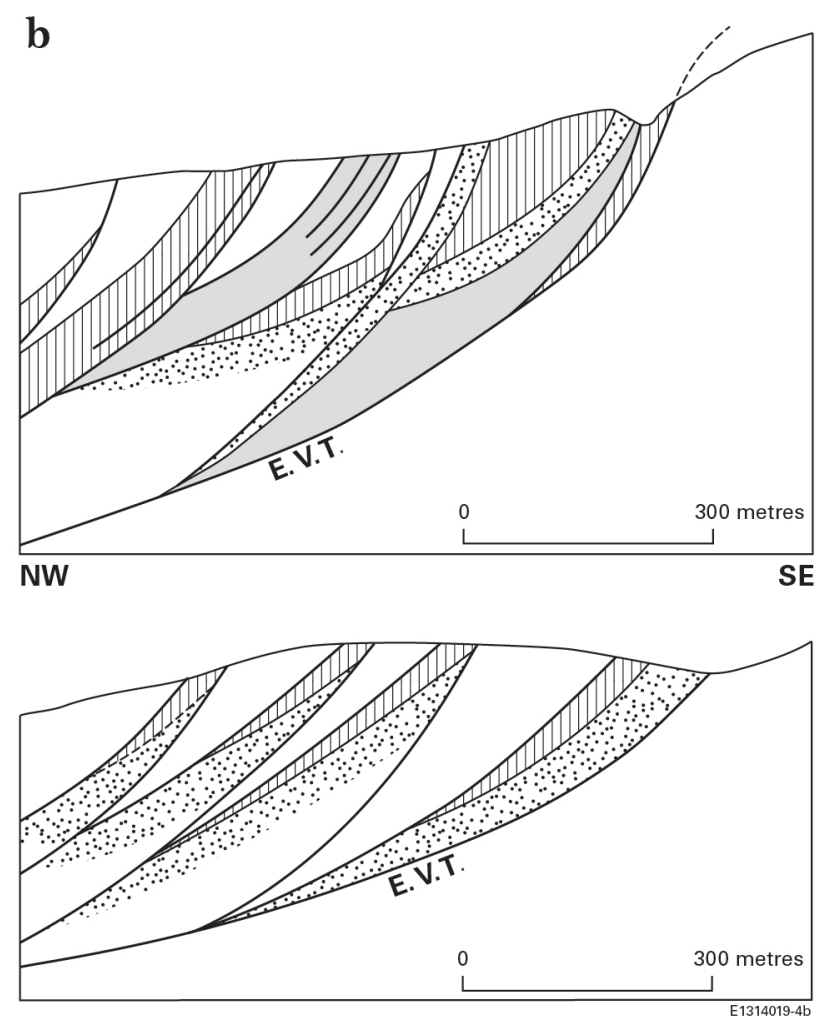
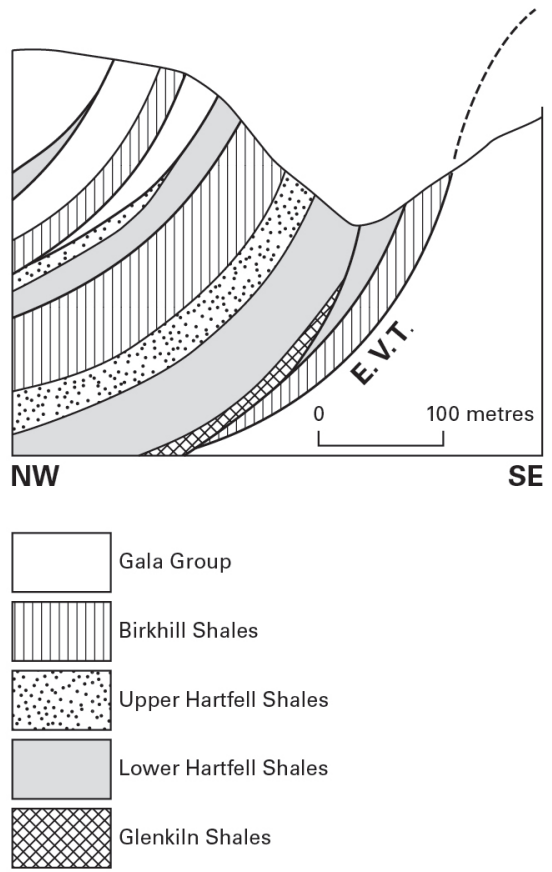

Stratigraphical contacts

Thrusts

E.V.T Ettrick ValleyThrust 


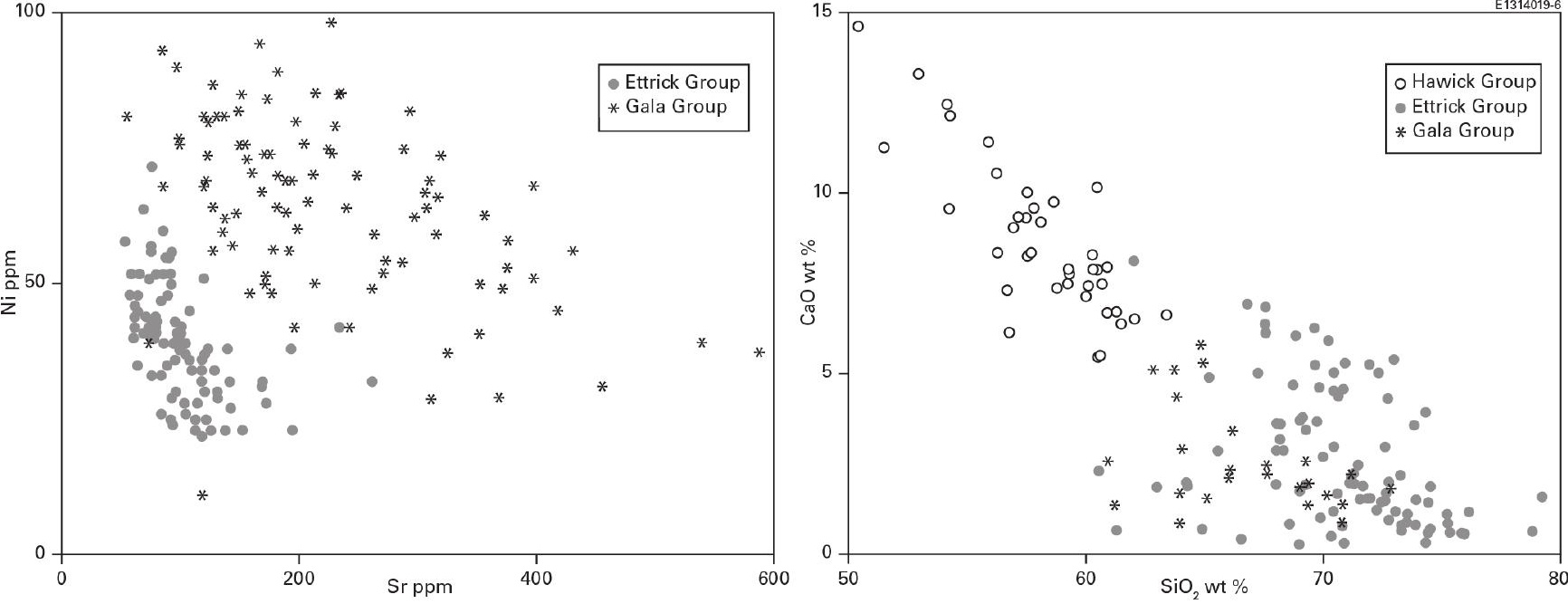




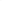




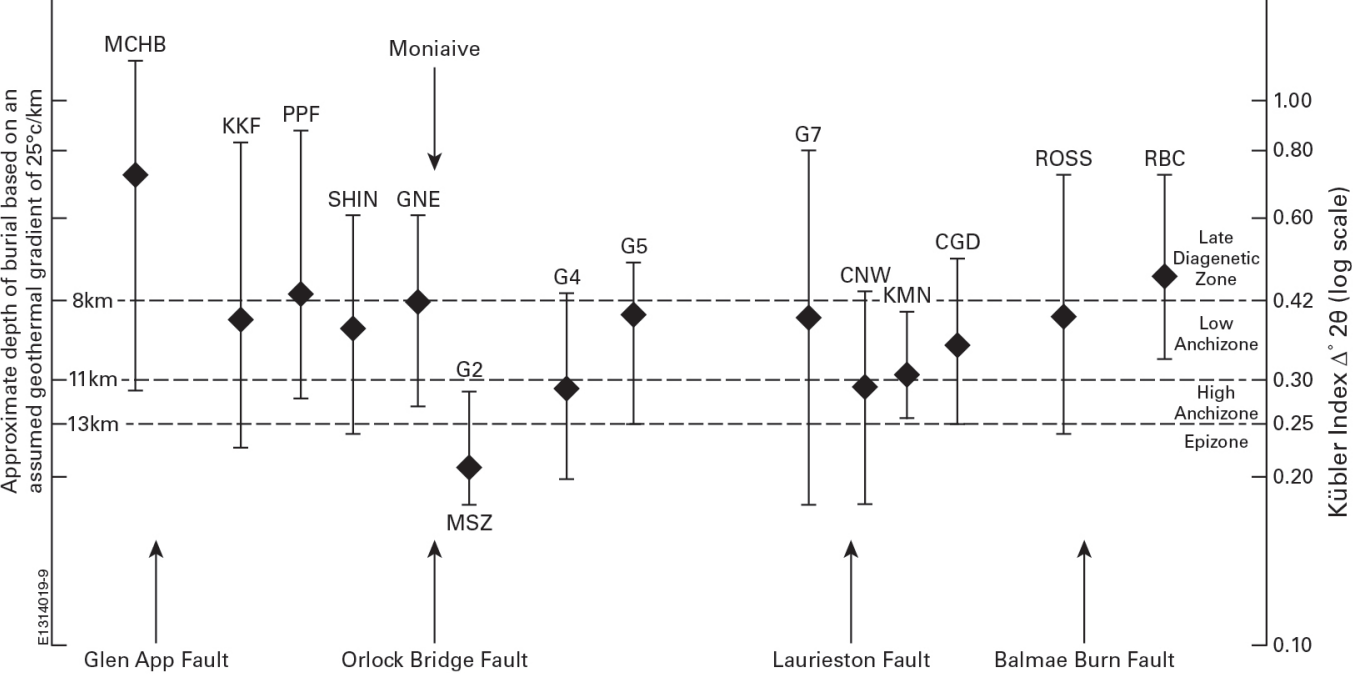

- Mean KI value 

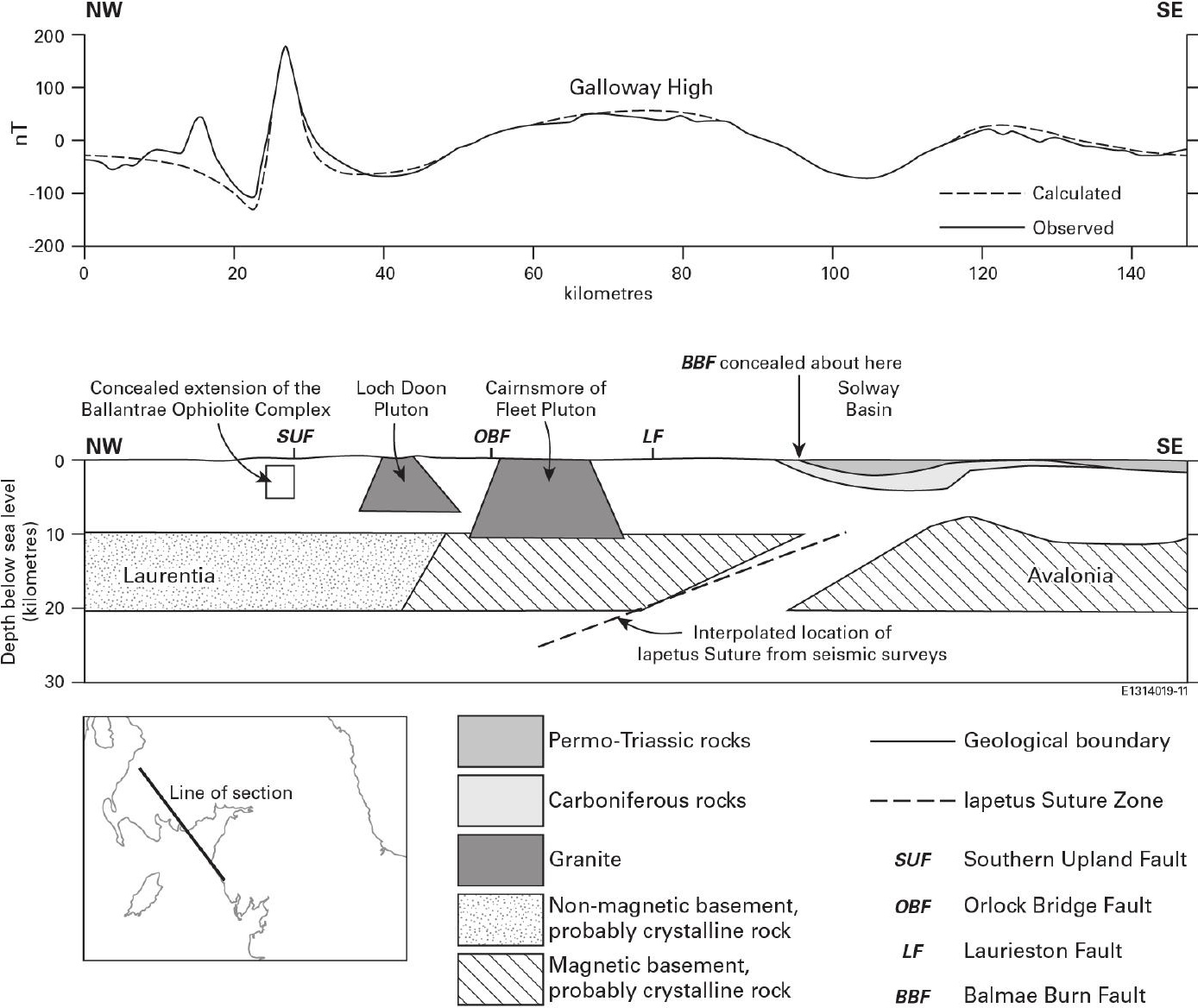
RICCARTON GROUP

\section{HAWICK GROUP}

Ross Formation

Carghidown Formation

Kirkmaiden Formation

Cairnharrow Formation

ETTRICK GROUP*

Glendearg Formation

Kirkhope Formation

Selcoth Formation

Thornylee Formation

\section{GALA GROUP}

Queensberry

Formation

Port Logan Formation

(Gala 8)

Mull of Logan

Formation (Gala 7)

Grennan Point

Formation (Gala 6)

Stinking Bight/Garheugh

Formation (Gala 5)

Sinniness/Float Bay

Formation (Gala 4)

Money Head Formation

(Gala 3)

Mindork Formation

(Gala 2)

Kilfillan Formation

(Gala 1)
LEADHILLS SUPERGROUP

SCAUR GROUP

Glenlee Formation

Shinnel Formation

Glenwhargen

Formation

Portpatrick

Formation

BARRHILL GROUP

Galdenoch Formation

Blackcraig Formation

Kirkcolm Formation

BAIL HILL

VOLCANIC GROUP

TAPPINS GROUP
Girvan Ordovician-

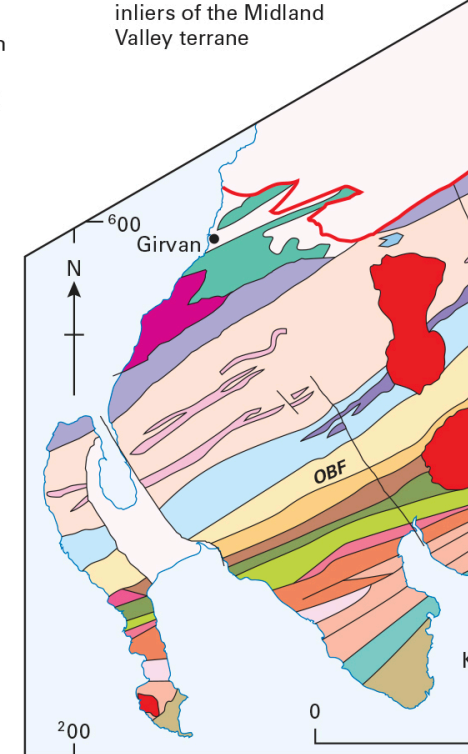

Silurian succession

Ballantrae Complex

Granitic Intrusions

Upper Palaeozoic and younger rocks, and Lower Palaeozoic inliers of the Midland Valley terrane

Geological boundary/fault

Boundary of region described in this guide
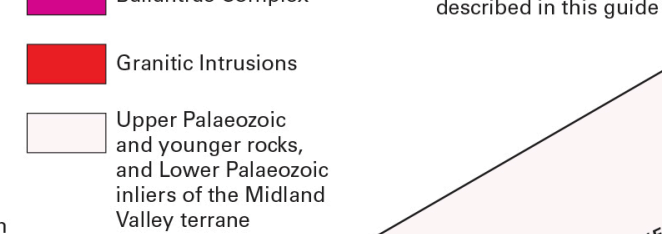
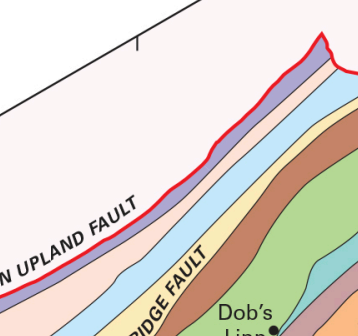

Dob's
Linn
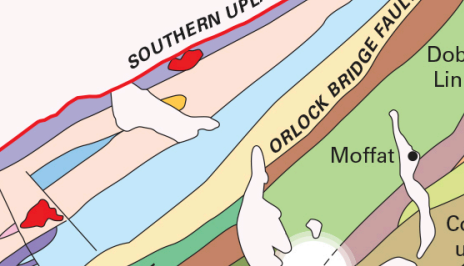

Correlation
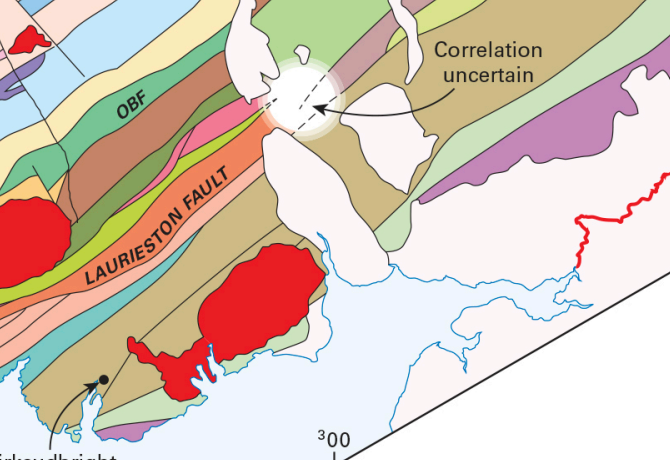

Kirkcudbright

25 kilometres

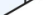

*The Grieston Formation (Ettrick Group) occupies Queensberry Formation (Gala Group) 